Portland State University

PDXScholar

Spring 9-11-2017

\title{
Influence of the Presidential Inaugural Address on Audience Perceptions of Candidate Image and the State of the Nation
}

Kyle Alexander Rush

Portland State University

Follow this and additional works at: https://pdxscholar.library.pdx.edu/open_access_etds

Part of the American Politics Commons, and the Communication Commons Let us know how access to this document benefits you.

\section{Recommended Citation}

Rush, Kyle Alexander, "Influence of the Presidential Inaugural Address on Audience Perceptions of Candidate Image and the State of the Nation" (2017). Dissertations and Theses. Paper 3806.

https://doi.org/10.15760/etd.5690

This Thesis is brought to you for free and open access. It has been accepted for inclusion in Dissertations and Theses by an authorized administrator of PDXScholar. Please contact us if we can make this document more accessible: pdxscholar@pdx.edu. 
Influence of the Presidential Inaugural Address

on Audience Perceptions of Candidate Image

and the State of the Nation

by

Kyle Alexander Rush

A thesis submitted in partial fulfillment of the requirements for the degree of

\section{Master of Science \\ in \\ Communication}

Thesis Committee:

Cynthia Lou Coleman, Chair

Lauren Frank

Lee Shaker

Portland State University

2017 
(C) 2016 Kyle Alexander Rush 


\begin{abstract}
This study asks whether and how the presidential inaugural address influences American audiences. The current study explores how the 2017 Presidential Inaugural Address of Donald Trump influences audiences. Two areas were studied: Candidate image and the state of the nation. I hypothesized that participants who watched the address would have different attitudes regarding candidate image and the state of the nation compared to non-viewers. I also hypothesized that viewers of the address who voted for Donald Trump would respond differently to candidate image and the state of the nation when compared with those who did not vote for Trump.

With one exception, none of the findings was significant. That is, attitudes of inaugural address viewers and non-viewers were similar, and attitudes of those who voted for the president and those who did not vote for the president were also similar. The exception was noted between those who voted for the candidate and oppositional voters: Those who voted for Donald Trump reported the nation is headed "in the right direction" while dissenters disagreed.

Keywords: inaugural address, president, image, election, political communication
\end{abstract}




\section{DEDICATION}

This master's thesis is dedicated to all the individuals who have supported me in getting to this point of my academic career and helped to shape me into the person I am today; to my friends, coworkers, professional staff, family, and cohort members who have provided me with a sounding board, and assisted with multiple rounds of edits. To all of the wonderful memories of graduate school and of Portland, Oregon that I will forever cherish in my heart and mind. 


\section{ACKNOWLEDGMENTS}

I want to send a special thank you to Dr. Cynthia Lou Coleman, my thesis advisor who has helped me greatly throughout the entire course of my graduate career. The time and energy you have provided me through multiple conversations, rounds of edits, and positive reinforcement are key components to my successful completion of this document. I also want to thank Dr. Lauren Frank and Dr. Lee Shaker for all of the assistance and support you have each provided me throughout this process. I truly appreciate the three of you for the time and energy you have spent assisting me throughout my academic career.

Additionally, I want to thank the entire faculty and staff within the Department of Communication at Portland State University, for all of the support and resources provided to me in the past two years. Dr. J. David Kennamer, I want to send a special appreciation to you for all our conversations and for being a wonderful friend to me throughout my stay at this institution. It means more to me than I can ever express.

To Daemian Evans, my best and truest friend, I want to thank you for always being there for me, in whatever capacity was necessary. Whether through conversations on the content of my thesis, the process, or simply a distraction to keep me mentally healthy throughout my graduate career. I can never thank you enough for the invaluable lessons you have provided me while being a part of my life.

A special thank you to the participants of my experiment and to my cohort members for all of the encouragement and friendship you have provided. Without the assistance of each of the prior stated individuals, I would not have been able to succeed with obtaining my master's degree. 


\section{TABLE OF CONTENTS}

Abstract..................................................................

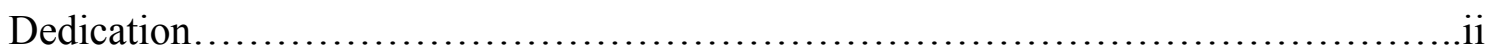

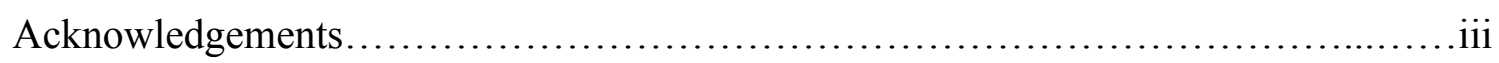

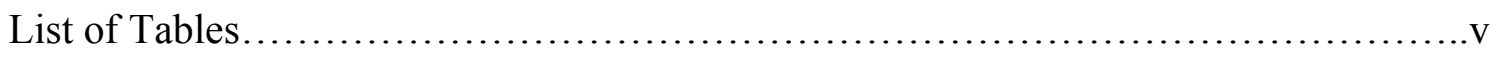

Chapter 1: Introduction..................................................

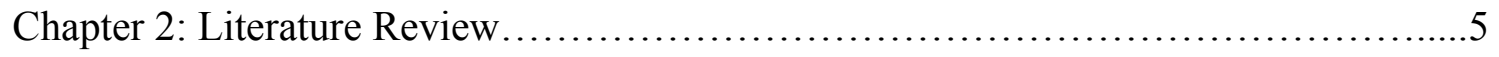

Chapter 3: Operationalization of Dependent Variables.............................24

Chapter 4: Methods......................................................27

Chapter 5: Findings....................................................... 34

Chapter 6: Discussion.................................................. 40

Chapter 7: The Learning Experience........................................49

References.............................................................. 51

Appendices............................................................60

Appendix A: Recruitment Script.....................................60

Appendix B: Course Website Post......................................61

Appendix C: Informed Consent Form...............................62

Appendix D: Survey Instrument....................................64

Appendix E: Participant Response Data Details...........................66

Appendix F: Footnotes..........................................69

Appendix G: Transcript of 2017 Presidential Inaugural Address...............70

Appendix H: Institutional Review Board Approval.........................73 


\section{LIST OF TABLES}

Table 1: Independent Samples $t$-test for Attributes of Candidate Image by Stimulus

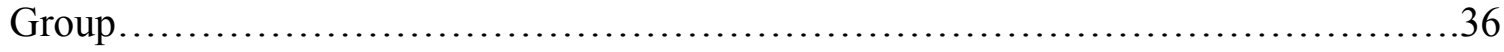

Table 2: Independent Samples $t$-test for Candidate Image by Voting Behavior...........36

Table 3: Independent Samples $t$-test for Components of State of the Nation by Stimulus Group............................................................... 38

Table 4: Independent Samples $t$-test for Components of State of the Nation by Voting

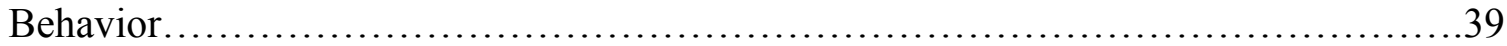




\section{CHAPTER 1: INTRODUCTION}

In the United States of America, every four years an important decision is made: who to elect as the next president. The election process captivates the attention of Americans for an extended length of time and concludes with an acceptance speech that the prevailing candidate presents, the inaugural address. This speech takes place in January, when the recently elected president to take office.

Copious amounts of research have focused on the presidential election process. Some have paid particular attention to news media (e.g. Brubaker \& Hanson, 2009; Landreville, White, \& Allen, 2015; Levendusky, 2010) and how the media have the ability to encourage citizens to take part in the election process (e.g. Kennamer, 1987). Research has focused on the structure and/or intent of presidential debates (e.g. Hart \& Jarvis, 1997) or the number of viewers who tune into the events (e.g. Cho \& Choy, 2011). Further research has been conducted on what influences voting decisions (e.g. Boydstun, Glazier, \& Pietryka, 1988), perceptions of candidates (e.g. Patterson, 1980), how debates affect voter decisions (e.g. Hill, Lo, Vavreck \& Zaller, 2013; Stroud, 2010), and how levels of political knowledge have increased (e.g. Weaver, 1996).

The presidential election demonstrates a president's successful understanding of the electorate, and how to communicate to citizens - it enhances his or her sense of solidarity with constituents (Baas \& Thomas, 1980). Research on presidential elections focuses attention upon debates; however, scholars have paid far less attention to the inaugural address. An election season does not end until the inaugural speech of the incoming president, when he or she takes the formal oath of office. 
It is important to examine inaugural addresses to have a full body of research encompassing the entire election process. Prior research has discussed the intent and purpose of inaugural addresses (Chung \& Park, 2010; Jamieson \& Birdsell, 1988; Ochs, 1979; Smith \& Smith, 1985). Scholars have examined how the text of the addresses is constructed (Kowal et al., 1997; Miller \& Stiles, 1986), and why the addresses are an integral part of the democratic process (Campbell \& Jamieson, 1990; Hart, 1984). Other research has examined inaugural address themes as they have changed over the years (Von Drehle, 1993; Whissell \& Sigelman, 2001). Studies on specific content presented by different presidents looked at either rhetorical analyses (Ford, 1989; McDiarmid, 1937; Sigelman, 1996) or content analyses (Ericson, 1997; Kinnier, Dannenbaum, Lee, Aasen, \& Kernes, 2004; Toolin, 1983). This wide range of research has focused on understanding inaugural addresses; however, researchers have neglected to examine the effects of such addresses upon the electorate.

Because presidential speeches may focus attention upon different policy areas, which may affect how citizens perceive policy, it is important to focus on whether inaugural addresses alter perceptions of candidate image and perceptions of the state of the nation. The current study will explore how presidential inaugural addresses influence these areas: candidate image and state of the nation. The setting for the study is the January 20, 2017 presidential inaugural address of Donald Trump (Trump, 2017).

Prior research findings surrounding the effects of presidential speeches upon the electorate will guide the research hypotheses regarding candidate image and perceptions of the state of the nation. Chapter 2 will review prior research conducted on inaugural addresses, followed by areas that appear to be limited in depth or breadth of research. 
This literature review will bring to light the limited research that has delved into the impacts the addresses hold upon audiences. This will follow with a justification for the present study's hypotheses, which state that viewers of the inaugural address will have more positive judgments of candidate image for the incoming president, and more positive perceptions of the state of the nation than those individuals who did not watch the address. Hypotheses also state that viewers of the address who did not vote for the incoming president will report higher judgment of candidate image and the state of the nation compared to those who did vote for the incoming president.

Chapter 3 will operationalize the scale used to assess candidate image and the questions used to assess different judgment of participant perspectives of the state of the nation. Candidate image is based upon a prior scale created by Miller and Miller's (1976) research into a similar field of study. State of the nation is assessed by evaluating audience opinions of the nation and a variety of policy areas, guided by prior research. Chapter 4 will detail the specific research method used to address hypotheses, discussing the experimental design for the present study. This will follow with an assessment of the 2017 Presidential Inaugural Address of Donald Trump, the artifact chosen for the present study. Chapter 5 will report the results of each statistical test conducted and the findings of a post-hoc analysis that presented itself. Results did not appear to show significant effects from the inaugural address upon perceptions of candidate image and the state of the nation, regardless of viewership or voting behavior. There was one exception discovered, that viewers of the inaugural address who voted for the incoming president appeared to hold higher judgment that the nation is headed in the right direction. 
Within Chapter 6, there will be an interpretation of the results within the present study and their contribution to inaugural address scholarship. Possible societal factors beyond the scope of the inaugural address speech itself and their potential influence upon the results of the present study will be discussed. Limitations to the present study are addressed, including issues with the sample size, variance of participants, and the gap in time between the presentation of the live inaugural address and the present study's experiment. This will follow with recommendations for venues of future research to continue studying presidential inaugural addresses. First, potentially conducting a mixedmethods study into inaugural addresses to build the bridge between two of the fields of research that appear to present themselves within inaugural address literature. Second, adaptations to the current research design which may have garnered deeper results. Third, an examination into the changing trend in the political environment toward a more selective and polarized audience. There are recommendations suggested to study the effects of the changing media environment beyond the presentation of the inaugural address as the present study examines. This paper concludes with Chapter 7 , that reviews the learning experience of the author, changes the researcher underwent through the completion of this thesis document, and lessons learned along the way. 
CHAPTER 2: LITERATURE REVIEW

Studying inaugural addresses can help us better understand the overarching political system (Chung \& Park, 2010). The literature review will discuss the purpose, message construction, and themes pertaining to presidential inaugural addresses. This follows with an overview of the scant research that explores the impacts inaugural addresses hold upon audiences. As Kubát and Cech (2016) have stated, research on inaugural addresses occurs frequently because the President of the United States holds one of the top political positions in the world.

\section{Inaugural Addresses}

Purpose. Presidential inaugural addresses are an important event for American politics. They are described as a "unidirectional speech presented by the president to the audience," meaning that the president has the ability to speak to the audience, without immediate audience feedback in a formal setting (Chung \& Park, 2010, p. 233). Inaugural addresses are the first opportunity for the newly elected president to discuss American politics and his or her role (Korzi, 2004). Inaugural addresses "wield the power of language" (Sigelman, 1996, p. 81), as they signal the start of a new president's term in office: the formal debut of the president to the public (Zhou \& Kazemian, 2015).

As Campbell and Jamieson (1990) have stated, inaugural addresses are "an essential element in the ritual of transition in which the covenant between the citizenry and their leaders is renewed" (p. 14). Inaugural addresses are the point in time when the president begins to "enact the presidential role" (Campbell \& Jamieson, 2008, p. 42). "Inaugurals mark the end of an election campaign and the beginning of a new administration" (Liu, 2012, p. 2409). 
The inaugural address has occurred every four years since the first president, George Washington, was elected in 1789. While it is not a required speech by the president, nor mandated by the Constitution (Smith et al., 2015), it has been given as a tradition (Kubát \& Cech, 2016). The speech was originally presented indoors to members of Congress until 1812, when it was moved outdoors due to reconstruction of the United States Capital Building. The event has been held outside ever since, and is now showcased to the world with the help of modern technology (Sigelman, 1996).

The address allows the president the opportunity to have immediate access of communication to all citizens (Ragsdale, 1984). This is important because politics do not constitute a daily concern for most citizens and such speeches must acquire citizen attention to overcome this barrier (Cohen, 1995). Regardless of political party affiliation, the addresses have aimed to speak to the public in its entirety rather than simply focusing upon fellow government officials (Ochs, 1979). Inaugural addresses allow the president to take sole possession of the stage and not compete with rival candidates (as occurs with presidential debates). The inaugural address is an important event for the incoming president, as national addresses offer a chance for the president to speak directly to citizens (Baum \& Kernell, 1999; Young \& Perkins, 2005).

Inaugural addresses may attempt to heal wounds, inspire nonpartisanship and consensus in America, and strive to establish national unity (Beasley, 2001). These speeches call for the support and loyalty not only from those involved in politics, but also from other members of society (Liu, 2012). Government officials are an important audience as they help to implement the president's agenda, but the public is also 
important, as the public is comprised of individuals who may choose to vote for the president if he or she runs for reelection (Whissel \& Sigelman, 2001).

The incoming president typically tries to push for party unification within the country just after election campaigns (Bitzer, 1992; Sigelman, 1996; Smith \& Smith, 1985). The speech is an opportunity to highlight traditional American values (Campbell \& Jamieson, 1990). Inaugural addresses are intended "to appeal to their countrymen to take pride in their country, to cherish her long-held traditions, and to put behind them the divisiveness of the past campaign and unite for the common good" (Rohler \& Cook, 1998, p. 243), and help with the transition of power from one president to the next (Cheng, 2006).

Campbell and Jamieson (1978) once tried to discover how similar elements occurred in inaugural addresses over the years, but were unable to acquire conclusive results at the time. After further studies, Campbell and Jamieson (1990) found four criteria that each inaugural address should attempt to accomplish. First, the audience needs to feel a sense of unity and the president needs to make each audience member feel like a part of "the people." Secondly, the inaugural address should discuss values from our nation's past. Thirdly, the president needs to address the principles that surround the new presidential administration and provide a sense of how his or her cabinet will work for the benefit of the nation as a whole. Finally, the inaugural address needs to show that the president has an understanding and is willing to do what is required of him or her, but also understands the limitations of the position. Each of these four elements attempts to leave the audience thinking introspectively, about how the incoming president's efforts 
will align with past leadership of the country to bring a bright future for the United States of America.

Message composition. Some presidents have created their own speeches for the inaugural addresses while others have used counsel to write the scripts (Emrich, Brower, Feldman, \& Garland., 2001; Gelderman, 1997; Miller \& Stiles, 1986). Even in instances where the president has the inaugural address prepared by speechwriters or by political advisors, the inaugural is still a product of the president and his or her goals (Whissell \& Sigelman, 2001). Regardless of who writes the message, most presidents seek counsel before presenting their speech (Chester, 1980). These auditory presentations of text prepared ahead of time are different from spontaneous speech; they are a performance, and are often triumphant in nature. Such speeches have evolved from being handwritten or typed messages to now using teleprompter to screen them for the president (Kowal et al., 1997).

Content. Inaugural addresses have varied greatly over the years (Campbell \& Jamieson, 1990) and across presidents from George Washington's first address in 1789 (Chung \& Park, 2010) to Barack Obama's address in 2013. Some speeches have been reflective and instructive to the nation, discussing strides the nation has taken to get to its present status and where it must venture forth (Ford, 1989).

A study of presidential inaugural addresses throughout American history found three distinct periods for the addresses: the constitutional period, the party period, and the plebiscitary period (Korzi, 2004). The constitutional period (prior to 1830) showed the president focusing on his role as the individual to enforce and uphold the constitution, not connected to the desire of the people or public opinion, but instead removed. For 
example, Thomas Jefferson's first inaugural address that focused a discussion upon discussing the principles that govern the union and the character of the republic, rather than upon the American public (Ceasar, Thurow, Tulis, \& Bessette, 1981).

The party period (the 1830 s to 1890 s) changed from a focus on the political party system's role to the construction of politics. There also became a focus on the will of the broader collective of citizens and the importance of campaigns and elections (Korzi, 2004). Abraham Lincoln's inauguration in 1861, placed attention upon addressing the American people more than just Congress, and discussed how the new administration would push to support the Constitution (Ceasar et al., 1981).

The plebiscitary period (1900s to present) portrays the president's role as the central and dominant position within the nation, with other components of the political process being absent, "such as Congress and political parties" (Korzi, 2004, p. 42). Woodrow Wilson in 1913 focused on discussing how the new administration reflects the principles of our national government and how the president will help make the vision of society into a reality (Ceasar et al., 1981).

Scholars have analyzed and compared inaugural addresses, and found similarities between the content, language themes, and verbal formulas used (Campbell \& Jamieson, 1990). Similarities between different inaugural addresses occurred despite party affiliation (Ericson, 1997). Addresses also appear to be similar whether a first term or a re-elected president administers them (Campbell \& Jamieson, 1985).

Whereas the inaugural addresses once distanced the president from the people, the speeches evolved into a focus on people and political parties, to now highlighting the ability of the president to act in his or her role. The speeches are no longer are as much 
about the position of the president, but appear to be about the person holding the position of the president instead.

Researchers have analyzed presidential addresses and report several trends. Toolin (1983) conducted research regarding 49 inaugural addresses from George Washington in 1789 to Ronald Reagan in 1981. Toolin found many similarities from one speech to the next (e.g., references to a deity and the United States Constitution). The similarity among speeches has led to a predictable script articulated by Von Drehle (1993). Von Drehle pointed out that inaugural addresses have four different components. The president begins with an introduction, consisting of an expression of humility, and how honored the president is to inherit his or her new position. The address then follows with a description of the president's rightful constitutional role and how the president will uphold the duties of the position. The president then outlines a few specific goals to accomplish in office. Lastly, the president concludes with a request for a blessing from God.

Ericson (1997) analyzed 52 inaugural addresses and found 11 major themes of American values. There were three "presidential humility" themes, which discussed how the president cannot succeed without the assistance of others. The first of these themes, contained in $50 \%$ of addresses, is "Cooperation with Congress," and discusses the president's need for the help of members of Congress to accomplish a joint agenda. As the addresses have focused more on "the people" rather than Congress over the years, this theme has declined over time. The second of the themes, present in $73 \%$ of addresses, is "Popular Support," which stresses the idea of the government being for the people, and the necessary support of society to help reach desired outcomes. The third theme, present 
in $100 \%$ of addresses, is a plea for the support of a divine being. While there were eight other themes commonly found throughout the addresses, ${ }^{1}$ the presidential humility themes are important to focus upon, as they appear to relate to audience perceptions of the president directly.

Other studies have examined inaugural addresses for enduring themes such as influencing a shared ideology within the American people (Beasley, 2001) or examined the emotional value and frequency of words used in the addresses (McDiarmid, 1937). While these studies looked at the composition of the messages themselves, none of these studies actually analyzed how the speeches affect the perspectives of audiences.

Rhetorical components. The way in which the speaker presents the inaugural address can hold more impact than the actual text of the speech (Kowal et al., 1997). The speaker must present the speech in a dignified way to hold positive impacts upon audiences (Bitzer, 1992; Jamieson, 1973), while none of these studies actually appeared to study audiences to see if these impacts did occur.

Neustadt (1991) discusses that the ability to persuade assists the president in the ability to hold power, and communication is key to presidents in order to possess authority. The inaugural address provides the opportunity for the president to communicate to his or her constituents in a variety of different ways, right from the start of the president's term in office. This allows audiences to see the president performing in his or her role for the first time. The address can provide citizens a sense of the tone (Mio, Riggio, Levin, \& Reese, 2005) or themes that affect the vision for the president's administration and the nation (Smith \& Smith, 1985). Specifically, inaugural addresses 
allow a way to display the administration's philosophy (Jamieson, 1973), goals, hopes,

and dreams, through a direct presentation to the nation (Chung \& Park, 2010).

Hoban (1980) discussed inaugural addresses as a form of epideictic speech:

They are delivered on ceremonial occasions, fuse past and future in present contemplation, affirm or praise the shared principles that will guide the incoming administration, ask the audience to "gaze upon" traditional values, employ an elegant, literary language, and rely on "heightening of effect," that is, on amplification and reaffirmation of what is already known and believed. (pp. 282283)

An epideictic speech attempts to win over the good will of an audience (Kennedy, 2003) and create unity (Brown, 2010). These speeches aim to "increase the intensity of adherence to values held in common by the audience and the speaker" (Perelman \& Olbrechts-Tyteca, 1969, p.52), and help create inspiration (Sheard, 1996). Text of a message requires interpretation beyond the meaning presented by the speaker, but also the impacts that the text has on audiences (Branham \& Pearce, 1985). The success or failure of each speech falls onto the audience's perceptions (Sheard, 1996).

Inaugural addresses offer a glimpse to the current relationship between the president and the public (Hart, 1984). Citizens are able to get a sense of the level of charisma the president possesses, and his or her rhetorical style, allowing citizens to understand the way the president conveys messages while holding office (Mio et al., 2005). These impacts are important, as the speech reaches a mass audience size (Sigelman, 1996). For the president to acquire and hold attention, audiences must be able to comprehend messages with ease (Emrich et al., 2001).

The speeches reveal information about the values, principles, and persona the president possesses, and aim to show why the president is the right person for the position (Liu, 2012). For more than two centuries, inaugural addresses have been a route to assist 
the president in governing the nation (Sigelman, 1996). While the president speaks to citizens, the nation feels a sense of shared promise (Ragsdale, 1984). The success of the speech does not appear to be due to the style or speaking ability of the incoming president (Ragsdale, 1987); rather, the success of the speeches appears to rely on the audience's reaction (Lucas, 1988). The incoming president should leave the stage having brought the audience together as one.

Audience impacts. Not only does the audience perceive and interpret the text of a message itself, but it also attempts to determine what the message means within a broader context, and in turn, may be affected personally by the message (Zarefsky, 2004). Direct impacts upon the audiences of inaugural address are an important aspect to analyze. Lucas (1988) discovered the impact of the speeches does not rely solely on the text of the message, but on "the progressive interaction of the audience with the temporal flow of ideational, dispositional, stylistic, and syntactical elements in the discourse" (p. 249). Stated another way, there are elements outside of the words spoken which may affect audiences (e.g., the tone of voice used by the speaker).

Research into public approval of the president has been conducted extensively (Druckman \& Holmes, 2004) and is important to understand, as the public is highly responsive to presidents (Cohen, 1995). Whissel and Sigelman (2001) discuss ways to help ensure these speeches impact audiences as intended. The messages need to be conveyed in a way for listeners to comprehend, by creating pictures within the audience's minds. Emotion and image-creating language do a better job at accomplishing these feats than complex messages, although this leads to a more shallow understanding of the president's agenda. Not only must the messages resonate with audience members, but 
they also need to appeal to the individual's emotions, leading to a variety of different impact and significance levels to different audience members (Emrich et al., 2001).

Even when reservations exist about a president, Americans generally view the president as an appropriate means to try to alter those perceptions (Ceasar et al., 1981). Major presidential speeches, such as the inaugural address, give the impression that the president is in charge of the nation and current political circumstances in our nation (Ragsdale, 1984). Through these speeches "the public is reassured that someone knows what needs to be done" (p. 983).

Few studies have analyzed the direct impacts of the inaugural address upon audiences. In one such study, Sigelman (1996) discovered a feeling of unity to be invoked in citizens through using first-person plural pronouns (e.g. our, we), or the use of symbols (e.g. the public, together). These tactics help establish a sense of togetherness, community, and unity (Biria \& Mohammadi, 2012; Wilson, 1990).

\section{Candidate Image}

Image attributes. To be an effective leader, the president must not only instruct the nation, but also inspire (Emrich et al., 2001). Druckman and Holmes (2004) found that the president may influence what citizens think of the president directly. The president attempts to acquire the necessary support from citizens and respond accordingly to what the public expects of the president within his or her position in office (Cohen, 1995). Cohen discusses that "the position of the president and the public's reliance on him makes anything that the president says important and influential" (p. 96). Little research appears to study directly the effects of speeches on perceptions of candidate 
image. Miller and MacKuen (1979) defined candidate image as "how positively or negatively the public viewed [a presidential candidate]" (p. 337).

Nimmo, Savage, and Mansfield (1974) discovered that identification with the incoming president improved following an inaugural address, with a particularly large magnitude from citizens who did not support that presidential candidate prior. This study assessed images of the general election presidential candidates by conducting surveys at three points in time: one day before the election, two weeks following the election, and directly after the incoming president's inaugural address.

In a study with methods that ran parallel to Nimmo et al. (1974), Baas and Thomas (1980) discovered the same results, with larger impacts on audience identification increases to occur because of the inaugural address in particular. The researchers found viewers identified more strongly with the incoming president (Jimmy Carter) after witnessing the address than the other two points in time surveyed. Those who changed their identification most strongly were individuals who had supported the opposing presidential candidate, who lost the election (Gerald Ford).

Assessment of candidate image is comprised of five dimensions of candidate attributes: competence, trust, reliability, leadership ability, and personality traits (Miller \& Miller, 1976). It is important to understand the five attributes individually, as they each play a role in the construction of one's image of another, in this case, the incoming president. Competence consists of audience views of the experience level and the ability of the president to perform his or her duties within the position. Trust is a combination of the perception of the president's honesty and integrity; it is how much citizens can count on the president to do as he or she promises. Reliability contains three components of 
responsibility, decisiveness, and stability - the perceived ability of the president to make tough decisions and perform despite the struggles of the position. Leadership ability regards one's perceptions on a candidate as being “inspiring, communicative, warm, and likeable" (Miller \& Miller, 1976, p. 330), these are emotions conveyed to citizens. Personality traits of a president contain aspects of personal appearance or demographic information such as age, sex, and physical appeal.

While we know that inaugural addresses have the ability to impact the ways in which audiences identify with an incoming president, I argue that we should inspect these speeches through an examination of the specific attributes of candidate image. Certain attributes of candidate image may influence some publics more than others. This leads me to the following five-part set of hypotheses:

H1A: Viewers of the 2017 Presidential Inaugural Address will report higher levels of competence for the incoming president than those who did not watch the address.

H1B: Viewers of the 2017 Presidential Inaugural Address will report higher levels of trust for the incoming president than those who did not watch the address.

H1C: Viewers of the 2017 Presidential Inaugural Address will report higher levels of reliability for the incoming president than those who did not watch the address.

H1D: Viewers of the 2017 Presidential Inaugural Address will report higher levels of leadership ability for the incoming president than those who did not watch the address. 
H1E: Viewers of the 2017 Presidential Inaugural Address will report higher levels of positive personality traits for the incoming president than those who did not watch the address.

Image effects overall. Ragsdale (1987) analyzed patterns of approval ratings for presidents in conjunction with different political events. This research discovered that following a presidential address, audiences are more willing to process and agree with the decisions presented by the speaker. Another study utilized a quasi-experimental research design, looking at audience members both before and after a key speech administered by President Ronald Reagan (Rosenblatt, 1998). Within this study, one group of participants viewed the speech, while the other group was not exposed to the speech. Not only did the speech alter perceptions of all audience members, but also the largest changes occurred among audience members who did not support the president prior to the speech.

It appears that inaugural addresses have the ability to increase positive perceptions of the incoming president. These impacts to audience perceptions are potentially one of the greatest benefits of the president giving an inaugural address. Those who did not vote for or know less about the incoming president, have been found to change their perceptions more than those who voted for or knew more about the president prior to the inaugural addresses, as discussed in prior findings (Baas \& Thomas, 1980; Nimmo et al., 1974). While inaugural addresses may alter perceptions that audiences hold for the incoming president, and these speeches may affect approval the most for those who did not vote for the incoming president, research has yet to examine these two occurrences together. This leads to my second hypothesis: 
H2: Viewers of the 2017 Presidential Inaugural Address who did not vote for the incoming president will report a greater positive judgment of candidate image of the president compared to viewers who voted for the incoming president.

\section{State of the Nation}

General and specific public support. Ragsdale (1984) argued that presidential speeches not only aim at influencing audience perceptions of candidate image, but also hope to change audience perceptions of the president's policy agenda. Communication from the president to the public is an important and effective way to alter opinions about public policy (Shull \& Ringlestein, 1993) and change the levels of support citizens hold for different policy areas (Jacobs \& Shapiro, 2000). Young and Perkins (2005) noted that while we know the president has the ability to influence public support, further research is necessary to understand the specific aspects that help to create this impact.

An issue area discussed as important surrounds the current economic situation within the nation, including all economic policies and problems (Cohen, 1995). Not only is the public concerned with the economy (Fordham, 1998), but so is the president, as the president is viewed positively when the economy is prosperous (Eshbaught-Soha \& Peake, 2005). This research leads me to include a question to assess how audiences view the current "economic situation" of our country.

Wood and Peake (1998) discuss the important role the president holds as the main source of information for foreign policy issues, including the president's communication to other nations (Cohen, 1995). Foreign policy includes the intervention of the United States military among other nations and the quantity of active duty personnel that exist (Young \& Perkins, 2005). Foreign policy has shown to differ from domestic policy 
(Wood \& Peake, 1998). Another study looked at audience perceptions of key speech on foreign policy administered by President Ronald Reagan, and discovered audiences to change their support for the foreign policy discussed within the speech (Rosenblatt, 1998). Chester (1980) noted the prominence of foreign relations mentioned within presidential inaugural addresses. This collective body of research leads me to include a second policy area question about "foreign policy."

Cohen (1995) discusses a third area of policy concern focused upon by presidents over the years, civil rights policy, which includes issues surrounding minority groups. Although discussed by Cohen as civil rights policy, Pew Research Center (Pew Hispanic Center, 2006) appears to use the term, social justice policy as a more modern term for the same type of policy area, aimed at assisting minority and marginalized groups within society. The importance of this policy area leads to a question to assess perceptions of "social justice policy."

In addition to prior research focusing upon the prior three policy areas (economic situation, foreign policy, and social justice policy), Pew Research Center appears to place a focus upon two other issue areas. These two policy areas are immigration policy; and environmental policy (e.g. Pew Research Center for the People \& the Press, 2010, 2014). Immigration policy, for the purposes of this question, is an area of policy that discusses the ways in which our nation governs individuals who come to our nation from other geographic locations beyond America's borders. Where foreign policy appears to focus upon how our nation interacts with other countries and leadership beyond our borders, immigration policy is a focus upon people within our country, or the ways in which people come and go from the nation's borders. Environmental policy, for the purposes of 
the present study, includes the ways in which America manages natural resources and tries to protect the world. This may include measures taken specifically to protect the environment or the harvesting of different sources of energy (e.g., wind, coal, oil). Environmental policy may include climate change and animal rights and areas of both renewable and non-renewable energy.

General viewpoints. Recall the standard intent and purpose of the inaugural addresses is to unify the nation, heal wounds caused from a divisive election (Beasley, 2001), and help audiences feel a shared promise for the nation (Ragsdale, 1984).

Campbell and Jamieson (1990) discussed the need for people to feel like the incoming president was working toward the benefit of the nation. While research has examined the effect inaugural addresses have on perceptions of candidate image, little is known of the influence these speeches have on other areas, such as the confidence in the country overall or upon different policy areas.

Inaugural addresses may affect how audiences hold perceptions of the state of the nation. I am using the term "state of the nation" to refer to how individuals feel about America at the current point in time. I will assess two general areas of personal opinion (satisfaction/dissatisfaction and direction the nation is headed), and whether the nation is doing poorly or good with regard to five specific policy areas (economic situation, foreign policy, immigration policy, social justice policy, and immigration policy). I argue the structure and purpose of the inaugural speeches can create the opportunity for the incoming president to influence positive audience perceptions of the state of the nation. Because a president can influence how audiences view the "state of the nation" in general or specific ways, I propose the following set of hypotheses: 
H3A: Viewers of the 2017 Presidential Inaugural Address will report a higher satisfaction in the nation than those who did not view the address.

H3B: Viewers of the 2017 Presidential Inaugural Address will report a more positive judgment that the nation is headed in the right direction than those who did not view the address.

H3C: Viewers of the 2017 Presidential Inaugural Address will report a more positive judgment of the nation's economic situation than those who did not view the address.

H3D: Viewers of the 2017 Presidential Inaugural Address will report a more positive judgment of the nation's foreign policy than those who did not view the address.

H3E: Viewers of the 2017 Presidential Inaugural Address will report a more positive judgment of the nation's immigration policy than those who did not view the address.

H3F: Viewers of the 2017 Presidential Inaugural Address will report a more positive judgment of the nation's social justice policy than those who did not view the address.

H3G: Viewers of the 2017 Presidential Inaugural Address will report a more positive judgment of the state of the nation's environmental policy than those who did not view the address.

\section{Influencing the Opposition}

Beasley (2001) discovered the president to be in a position not only to bring about ideals, but also to alter pre-existing ones. Hagner and Reiselbach (1978) found candidate 
image to increase the most when the audience was not familiar with the candidate, and the inverse to be true as well. Other studies that found audience perceptions of candidates to increase the most when the viewer did not support the incoming president prior to their election into office (Baas \& Thomas, 1980; Nimmo et. al., 1974), and approval ratings of a president to increase the most from those who did not vote for him or her (Rosenblatt, 1988). In other words, perceptual changes onto political images appear to be highest for those individuals who did not support the president prior to their election.

With this in mind, I argue that those viewers of the inaugural address who did not vote for the incoming president will have higher perceptions of the "state of the nation" than viewers who did vote for the president. This leads me to my final set of hypotheses:

H4A: Viewers of the 2017 Presidential Inaugural Address who did not vote for the incoming president will report satisfaction in the nation compared to those who did vote for the incoming president.

H4B: Viewers of the 2017 Presidential Inaugural Address who did not vote for the incoming president will report a more positive judgment that the nation is headed in the right direction compared to those who did vote for the incoming president.

H4C: Viewers of the 2017 Presidential Inaugural Address who did not vote for the incoming president will report a more positive judgment of the nation's economic situation compared to those who did vote for the incoming president. H4D: Viewers of the 2017 Presidential Inaugural Address who did not vote for the incoming president will report a more positive judgment of the nation's foreign policy compared to those who did vote for the incoming president. 
H4E: Viewers of the 2017 Presidential Inaugural Address who did not vote for the incoming president will report a more positive judgment of the nation's immigration policy compared to those who did vote for the incoming president. H4F: Viewers of the 2017 Presidential Inaugural Address who did not vote for the incoming president will report a more positive judgment of the nation's social justice policy compared to those who did vote for the incoming president.

H4G: Viewers of the 2017 Presidential Inaugural Address who did not vote for the incoming president will report a more positive judgment of the nation's environmental policy compared to those who did vote for the incoming president. 
CHAPTER 3: OPERATIONALIZATION OF DEPENDENT VARIABLES

For the purposes of the different hypotheses of this research study, it is important to understand not only what is studied, but also the ways in which specific measurements will be utilized to appropriately measure data. This chapter will not only detail the items utilized to assess perceptions of candidate image, but also the justification for why specific information was sought out to assess audience images of the state of the nation. Prior studies into similar fields of research will be addressed to help justify the different questions asked of participants to help understand the results of this study.

\section{Operationalizing Candidate Image}

To examine perceptions of candidate image, the present study used Miller and Miller's (1976) scale. Each variable of candidate image (competence, reliability, leadership ability, personality traits, and trust) was measured independently. I made one alteration to Miller and Miller's scale. Whereas participants were asked about the "personality traits" of the incoming president in the past, the current study asked participants about the "positive personality traits" of the incoming president. This was to ensure participants did not answer the quantity of how many general personality traits Donald Trump possesses, but rather how positively they viewed his personality traits.

The candidate image question asked:

"Please evaluate Donald Trump with how much you believe he possesses the following characteristics. (Please circle the best answer option for each line)"

- Competence

- Reliability

- Leadership Ability

- Positive Personality Traits

- Trust 
For each of these answer choices, participants were presented a Likert-type question asking them to rate the incoming president on each attribute, including $1=$ None at all, 2 $=A$ little, $3=A$ moderate amount, $4=A$ lot , and $5=$ An extreme amount $($ see Appendix D for the Survey Instrument). To test hypothesis 2, I created an additive scale for candidate image of five variables. Reliability was conducted for the scale, resulting in a Cronbach's alpha of $\alpha=.93$.

\section{Operationalization of State of the Nation}

My explication of the state of the nation includes two different entities: the perceptions of audiences about (a) the nation in general and (b) specific policy areas.

State of the nation included two questions from the Pew Research Center ${ }^{2}$ (Pew Research Center for the People \& the Press, 2001, 2013). The first question asked participants about their satisfaction of the nation:

"All in all, are you satisfied or dissatisfied with the way things are going in the nation today?"

Answer choices were: 1 =Very Satisfied, 2 =Satisfied, $3=$ Content, $4=$ Dissatisfied, and $5=$ Very Dissatisfied. Responses were reverse-coded so Very Satisfied $=5$ and Very Dissatisfied $=1$. The second question asked participants about the direction the nation is headed:

"All in all, do you think things in the nation are generally headed in the right direction, or do you think things are headed in the wrong direction?" Likert-type responses included: $1=$ Greatly in the Right Direction, $2=$ Slightly in the Right Direction, 3 = Staying in the Same Spot, 4 = Slightly in the Wrong Direction, and 5 
= Greatly in the Wrong Direction. Responses were reverse-coded so Greatly in the right Direction $=5$ and Greatly in the Wrong Direction $=1$.

I also asked participants their views on five different policy areas. Follows is the question wording:

"Please answer the following questions regarding your view of the state of the nation today. (please circle the best answer option for each line)"

- Economic Situation

- Foreign Policy

- Immigration Policy

- Social Justice Policy

- Environmental Policy

For each of these policy areas, participants were presented a Likert-type scale asking them to rate the incoming president on each attribute, including $1=$ Very Poor, $2=$ Poor, $3=$ Okay, $4=$ Good, and $5=$ Very Good (see Appendix D for the Survey Instrument). The specific answer choices to these questions was developed during the current study to account for a wide range of participant judgment responses. 
CHAPTER 4: METHODS

\section{Participants and Recruitment}

This study sought a purposive sample of college students 18 years of age and older. These individuals allow for a convenient sample of participants. Participants for the study were recruited from a subject pool of undergraduate students enrolled in four communication courses at a large-sized university in the Pacific Northwest (see Appendix A for the recruitment script). Students were offered extra credit as an incentive to participate. If students were unable to attend the research study, there was an alternative extra credit assignment provided, which would take comparable time and energy as the experiment to complete.

The inaugural address took place on Friday, January 21, 2017, however the experiment was conducted on Monday, January 30, 2017. Participants were asked to arrive at 4:30 p.m. The experiment took place in two auditorium lecture halls, in a central building on campus. The university's Institutional Review Board (IRB) approved this study design (see Appendix H for IRB approval document).

The sample consisted of 57 undergraduate students: $57.9 \%$ participants $(n=33)$ were randomly assigned to the control group, which viewed a comedy television sitcom. There were $42.1 \%$ participants $(n=24)$ who were randomly assigned to the treatment group. The treatment group viewed the entire 18-minute 2017 Presidential Inaugural Address of Donald Trump. The participants' mean age for the sample was 24.4 (SD = 6.0), and ranged from 19 to 52 years of age. The sample included $29.8 \%$ males $(n=17)$ and $70.2 \%$ females $(n=40)$. The ethnicities for respondents consisted of $54.4 \%$ 
White/Caucasian $(n=31), 7.0 \%$ African American $(n=4), 8.8 \%$ Asian American $(n=$ 5), $10.5 \%$ Hispanic $(n=6)$, and $10.5 \%$ Other $(n=6)$.

\section{Procedures}

The stimulus group $(n=24)$ was shown the 2017 Presidential Inaugural Address of Donald Trump while the control group $(n=33)$ was shown an episode of a comedy television sitcom. The 2017 Presidential Inaugural Address was obtained from the network CSPAN, via YouTube. The comedy episode was unrelated to politics in content, and ran the same length of time as the experimental stimulus video.

Upon arrival at the check-in table, each participant received an informed consent form (see Appendix C) to complete. The consent form notified participants of the research's purpose, described as collecting "information about perceptions of politics." This form noted that participation was elective (not mandatory), and confidentiality would be ensured. Participants were notified of their ability to withdraw from the experiment at any time without any negative sanctions.

After completing the consent forms, participants were sorted into two groups. Randomization of participants was accomplished using a mobile application that digitally flipped a coin: participants with a "head" on the coin were placed in the control group, while participants with a "tails" were placed in the experimental treatment group. The study's author handed each participant a slip of paper, which designated which room he or she was assigned to. At approximately 4:45 p.m. a proctor ${ }^{4}$ in each classroom started the video. Once participants completed their viewing of the programs, they completed the paper survey (see Appendix D). The survey was identical for both stimulus groups. Upon 
completion of the survey, participants were thanked for their time and dismissed from the study. $^{5}$

\section{Measures}

Candidate image. As noted in the previous chapter, candidate image was assessed using Miller and Miller's (1976) five attributes to assess candidate image (competence, reliability, leadership ability, positive personality traits, and trust). For each

of these attributes, participants were presented a Likert-type questions asking them to rate the incoming president on each attribute, including $1=$ None at all to $5=$ An extreme amount (see Appendix D for the Survey Instrument).

State of the nation. As noted in the prior chapter, state of the nation included two questions assessing perception of public policy from the Pew Research Center as follows: "All in all, are you satisfied or dissatisfied with the way things are going in the nation today?"

"All in all, do you think things in the nation are generally headed in the right direction, or do you think things are headed in the wrong direction?"

Participants were also asked about their perceptions of different policy areas (Economic Situation, Foreign Policy, Immigration Policy, Social Justice Policy, and Environmental Policy). For each of these policy areas, participants were presented a Likert-type question asking them to rate the incoming president on each attribute, including $1=$ Very Poor to 5 $=$ Very Good (see Appendix D for the Survey Instrument). Higher scores indicate a more positive perception of that specific issue area in the nation. 


\section{Political Demographics}

The survey asked a series of questions that may influence political judgments.

Participants were asked, "How many presidential debates did you watch during the 2016 presidential general election?" Answer choices were: $1=$ None, $2=$ One, and $3=$ Two, and $4=$ Three. Participants were asked: "Which of the following is your political ideology?" Answer choices were: 1 = Very Liberal, 2 = Slightly Liberal, $3=$ Moderate/Middle of the Road, $4=$ Slightly Conservative, $5=$ Greatly Conservative.

The next set of questions asked participants about their voting behavior. The first question asked "Are you registered to vote?" Answer choices were: $1=Y e s, 2=$ No, and 3 = Prefer not to answer. The next question asked: "Did you vote in the 2016 presidential general election?" Answer choices mirrored the prior question: $1=Y e s, 2=N o$, and $3=$ Prefer not to answer. Participants were asked to disclose their political party identification on a 5-point Likert scale, including $1=$ Strong Democrat, $2=$ Weak Democrat, 3 = Independent/Neutral, $4=$ Weak Republican, and $5=$ Strong Republican. The survey asked: "For whom did you vote as President of the United States?" Answer choices were: 1 = Hillary Clinton, 2 = Gary Johnson, 3 = Jill Stein, $4=$ Donald Trump, and $5=$ Other

To acquire a better understanding of exposure levels of the address overall, I asked how much of the inaugural address participants watched prior to the study on a 5point Likert-type scale from $1=$ None at all, $2=$ Less than half, $3=$ About half of it, $4=$ More than half, and $5=$ All of it. The questionnaire also asked all participants how much attention was paid to the inaugural address on a 5-point Likert-type scale, including $1=$ None at all, $2=$ A little, $3=A$ moderate amount, $4=A$ lot, and $5=$ All of $i t$. Lastly, 
participants were asked: "Did you participate in any inauguration protests and/or marches?" Answer choices were: $1=$ Yes, $2=$ No, and $3=$ Prefer not to answer.

\section{Analysis of Artifact}

Before discussing the results and contributions of this study, it is first important to briefly review the 2017 Presidential Inaugural Address of Donald Trump as an artifact of study. Ericson's (1997) content analysis of 52 presidential inaugural addresses discovered 11 themes typically present within addresses over the years. To help readers understand the 2017 inaugural address, I read the text for the presence of the themes noted by Ericson. Following are my observations of the address (see appendix $G$ for the full text of the inaugural address).

Nonpartisanship. The theme of nonpartisanship entails the president warning society about the danger of political parties within our nation. This theme was present within the current artifact, as shown with the line, "What truly matters is not which party controls our government, but whether our government is controlled by the people." This line discusses how society should not be focusing upon political parties, but rather a focus on the people as a collective position of power.

National unity. The national unity theme entails the president discussing divisions within the nation, and how we need to come together as one for the greater good. This theme can be witnessed within the words, "We, the citizens of America, are now joined in a great national effort to rebuild our country and restore its promise for all of our people. Together we will determine the course of America and the world for many, many years to come" and the words, "When America is united, America is totally unstoppable." These lines discuss how all citizens need to come together to help set the 
path for the nation as a collective, create a brighter future, and accomplish whatever America sets its collective mind to.

General policy principles. The theme of general policy principles regards the president discussing the policies he will push for while in office. This theme showcased itself within a variety of lines within the current address. A few examples are as follows, “We've defended other nations' borders while refusing to defend our own and spent trillions and trillions of dollars overseas," "We must protect our borders from the ravages of other countries making our products, stealing our companies and destroying our jobs," and "We will bring back our jobs. We will bring back our borders." Each of the prior quotes discusses different general policy principles the president supports, such as domestic border control and bringing jobs back to America from other countries.

Providential supreme being. Providential supreme being is a theme that seeks to place the president in a position of humility as the president acknowledges their limited power within the position, and the need for the support of God. This theme can be found in the line, "We will be protected by the great men and women of our military and law enforcement and, most importantly, we will be protected by God.” While there were other mentions to God within the speech, this line was spoken in a way to call for the need of support from a higher power, as opposed to other mentions of a supreme being within the speech such as "God bless America."

American mission. The theme of the American mission includes the idea that while America spreads its influence around the world, we should assist other nations while not pushing our ideas on them at the same time. This theme can be found within the lines of the speech "We will seek friendship and goodwill with the nations of the world, 
but we will do so with the understanding that it is the right of all nations to put their own interests first," and "We do not seek to impose our way of life on anyone, but rather to let it shine as an example." Each of these lines discusses how we hope to improve the current relations and situation with other nations of the world, but also not push America's agenda upon other nations.

Political continuity. The political continuity theme involves the president noting the importance of a stable government and continuing to keep this stability. This theme occurred more in the past, but can be found in the line "We will reinforce old alliances and form new ones." This infers America will be keeping stability with preexisting international relations, while furthering positive relations with other nations.

Themes not present. While six of the eleven themes found prominent within Ericson's (1997) content analysis were present, there were also five themes not present in the 2017 Presidential Inaugural Address. The first missing theme was civic virtue, where the president asks audiences to give up something personal and help fulfill a duty for the nation. There were two themes of presidential humility not mentioned including cooperation with Congress (needing the support of Congress for the president to succeed), and popular support (asking the American people specifically to help the president govern in their position, while the third theme of presidential humility (a providential supreme being) was present. The fourth theme not present is the defender of the constitution, where the president vows to uphold to Constitution of the United States of America. The fifth and last theme not present is federalism. This theme is tied to civic virtue, and explicitly discusses the rights held by the individual states. 
CHAPTER 5: FINDINGS

Overall, most respondents identified as liberal, with $31.6 \%(n=18)$ very liberal, $36.8 \%(n=21)$ slightly liberal, $14.0 \%(n=8)$ moderate/middle of road, $8.8 \%(n=4)$ slightly conservative, and $7.0 \%(n=4)$ very conservative, while $1.8 \%(n=1)$ declined to answer this question $(M=2.2, \mathrm{SD}=1.2)$. Responses codes ranged from very liberal (1) to very conservative (5). Questions of voting behaviors showed 90.9\% $(n=50)$ were registered to vote, $7.3 \%(n=4)$ were not, while $1.8 \%(n=1)$ preferred not to answer the question. Of all participants, $70.9 \%$ voted in the recent election $(n=39)$, while $29.1 \%$ did not vote $(n=16)$. Self-identification of political party identification showed $26.3 \%(n=$ $15)$ as strong democrat, $38.6 \%(n=22)$ as weak democrat, $17.5 \%(n=10)$ as independent/neutral, $12.3 \%(n=7)$ as weak republican, and 5.3\% $(n=3)$ as strong republican $(M=2.3, \mathrm{SD}=1.2)$. Response codes ranged from strong democrat (1) to strong republican (5). Half $(50.9 \%)$ of participants $(n=28)$ voted for Democratic candidate Hillary Clinton; $12.7 \%(n=7)$ voted for Republican candidate Donald Trump; $1.8 \%(n=1)$ voted for Libertarian candidate Gary Johnson; 3.6\% $(n=2)$ voted for Green Party candidate Jill Stein; $1.8 \%(n=1)$ voted for another candidate; while $29.1 \%(n=$ 16) participants did not vote. ${ }^{3}$

About $33.3 \%(n=19)$ of people had seen none of the inaugural address, while $26.3 \%(n=15)$ watched less than half, $7.0 \%(n=4)$ watched about half, $8.8 \%(n=5)$ watched more than half, $22.8 \%(n=13)$ watched all of it prior, while $1.8 \%(n=1)$ declined to answer the question $(M=1.6, \mathrm{SD}=1.6)$. Response codes ranged from none of the address (0) to all of the address (4). Of all participants, $8.8 \%(n=5)$ stated they had paid no attention to the address, while $17.5 \%(n=10)$ paid a little attention, $22.8 \%(n$ 
$=13)$ paid a moderate amount of attention, $28.1 \%(n=16)$ paid a lot of attention, $5.3 \%$ $(n=3)$ paid an extreme amount of attention, while $17.5 \%(n=10)$ declined to answer the question $(M=1.96, \mathrm{SD}=1.1)$. Response codes ranged from paid no attention $(0)$ to paid an extreme amount of attention (4). As for debates, only $12.3 \%(n=7)$ viewed no debates, $26.3 \%(n=15)$ viewed one debate, $40.4 \%(n=23)$ viewed two debates, and $21.1 \%(n=12)$ watched all three debates $(M=1.7, \mathrm{SD}=0.9)$. Response codes ranged from no debates (0) to all three debates (3). When asked if they took part in any inauguration protests and/or marches, $28.1 \%(n=16)$ of participants did, $68.4 \%(n=39)$ did not, while $3.5 \%(n=2)$ preferred not to answer this question.

The five-part set of Hypotheses 1 (A-E) predicted that viewers of the 2017 Presidential Inaugural Address would report higher levels of candidate image attributes (competence, trust, reliability, leadership, and positive personality traits) than those who did not watch the address. An individual-samples $t$-test compared perceptions of each candidate image attribute between those who watched the inaugural address $(n=24)$ and those who did not $(n=10)$, specifically looking at participants within the control group who reported not viewing any of the inaugural address prior to the study (see Table 1).

There was no significant difference in the means for those who watched the inaugural address $(M=1.25, S D=1.26)$ compared with those who did not watch the address $(M=1.44, S D=1.51)[t(12.43)=-0.4, p=0.7]$, with regard to the candidate's competence. There was no significant difference in the scores for those who watched the inaugural address $(M=1.0, S D=1.29)$ and those who did not watch the address $(M=$ $0.70, S D=1.06)[t(20.42)=-0.5, p=0.5]$, with regard to the candidate's reliability. There was no significant difference in the scores for those who watched the inaugural 
address $(M=1.25, S D=1.29)$ and those who did not watch the address $(M=1.20, S D=$ 1.14) $[t(19.18)=-0.1, p=0.9]$, with regard to the candidate's leadership ability. There was no significant difference in the scores for those who watched the inaugural address $(M=0.71, S D=1.0)$ and those who did not watch the address $(M=0.90, S D=1.20)[t$ $(14.50)=0.04, p=0.7]$, with regard to the candidate's positive personality traits. There was no significant difference in the scores for those who watched the inaugural address $(M=0.88, S D=1.19)$ and those who did not watch the address $(M=0.70, S D=1.34)[t$ $(15.28)=-0.4, p=0.7]$, with regard to the candidate's trust.

\begin{tabular}{|c|c|c|c|c|c|c|c|c|c|}
\hline \multicolumn{10}{|c|}{ Table 1: Independent Samples t-test for Attributes of Candidate Image by Stimulus Group* } \\
\hline & \multicolumn{3}{|c|}{$\begin{array}{c}\text { Control } \\
\text { Group }\end{array}$} & \multicolumn{3}{|c|}{$\begin{array}{c}\text { Treatment } \\
\text { Group }\end{array}$} & \multirow[t]{2}{*}{$\begin{array}{c}95 \% \text { CI for } \\
\text { Mean Difference }\end{array}$} & \multirow[b]{2}{*}{$\mathrm{t}$} & \multirow[b]{2}{*}{ df } \\
\hline & $M$ & $\mathrm{SD}$ & $\mathrm{n}$ & $M$ & SD & $\mathrm{n}$ & & & \\
\hline Competence & 1.44 & 1.51 & 9 & 1.25 & 1.26 & 24 & $-1.032,1.421$ & 0.4 & 12.43 \\
\hline Reliability & 0.70 & 1.06 & 10 & 1.00 & 1.29 & 24 & $-1.186,0.586$ & -0.7 & 20.42 \\
\hline Leadership Ability & 1.20 & 1.14 & 10 & 1.25 & 1.29 & 24 & $-0.982,0.882$ & -0.1 & 19.18 \\
\hline Positive & 0.90 & 1.20 & 10 & 0.71 & 1.0 & 24 & $-0.728,1.111$ & 0.4 & 14.50 \\
\hline Personality Traits & & & & & & & & & \\
\hline Trust & 0.70 & 1.34 & 10 & 0.88 & 1.19 & 24 & $-1.213,0.863$ & -0.4 & 15.28 \\
\hline
\end{tabular}

Hypothesis 2 predicted that viewers of the 2017 Presidential Inaugural Address who did not vote for the incoming president would report a higher positive perception of candidate image compared to viewers who voted for the incoming president. There were significant differences between for those who watched the inaugural address and voted for the incoming president ( $\mathrm{n}=4, M=2.8, S D=0.94)$ and those who did not vote for the incoming president $(\mathrm{n}=14, M=0.50, S D=0.54)[t(3.58)=4.7, p=0.012]$, with regard to candidate image overall (see Table 2).

\begin{tabular}{|lcccccccccc|}
\hline \multicolumn{4}{|c|}{ Table 2: Independent Samples t-test for Candidate Image by Voting Behavior } \\
\hline & \multicolumn{4}{|c|}{$\begin{array}{l}\text { Voted for } \\
\text { Incoming President }\end{array}$} & & \multicolumn{2}{c|}{$\begin{array}{c}\text { Did not Vote for } \\
\text { Incoming President }\end{array}$} & $\begin{array}{c}95 \% \text { CI for } \\
\text { Mean Difference }\end{array}$ & & \\
& $M$ & SD & $\mathrm{n}$ & & $M$ & SD & $\mathrm{n}$ & & $\mathrm{t}$ & $\mathrm{df}$ \\
\hline Candidate Image & 2.80 & 0.94 & 4 & & 0.50 & 0.54 & 14 & $0.873,3.727$ & 4.7 & 3.58 \\
\hline
\end{tabular}


The seven-part set of hypotheses 3 (A-G) predicted that viewers of the 2017 Presidential Inaugural Address would have a more positive judgment of the state of the nation than those who did not view the inaugural address (see Table 3 ). There was no significant difference with regard to levels of satisfaction of the nation for those who watched the inaugural address $(\mathrm{n}=24, M=1.83, S D=1.05)$ compared with those who did not watch the address $(\mathrm{n}=10, M=2.30, S D=1.49)[t(12.87)=0.9, p=0.385]$. There was no significant difference with attitudes about the direction the nation is headed for those who watched the inaugural address $(\mathrm{n}=24, M=2.17, S D=1.44)$ and those who did not watch the address $(\mathrm{n}=9, M=1.44, S D=1.01)[t(20.50)=-1.6, p=0.122]$. There was no significant difference with attitudes about the economic situation for those who watched the inaugural address $(\mathrm{n}=23, M=2.78, S D=0.74)$ and those who did not watch the address $(\mathrm{n}=10, M=2.70, S D=0.68)[t(18.67)=-0.3, p=0.757]$. There was no significant difference with attitudes about foreign policy for those who watched the inaugural address $(\mathrm{n}=23, M=2.48, S D=0.89)$ and those who did not watch the address $(\mathrm{n}=10, M=2.20, S D=0.63)[t(24.11)=-0.9, p=0.320]$. There was no significant difference with attitudes about immigration policy for those who watched the inaugural address $(\mathrm{n}=24, M=2.00, S D=0.89)$ and those who did not watch the address $(\mathrm{n}=10$, $M=1.80, S D=0.79)[t(18.88)=-0.6, p=0.524]$. There was no significant difference with attitudes about social justice policy for those who watched the inaugural address (n $=24, M=2.29, S D=0.96)$ and those who did not watch the address $(\mathrm{n}=10, M=2.00$, $S D=0.82)[t(19.67)=-0.9, p=0.378]$. There was no significant difference with attitudes about environmental policy for those who watched the inaugural address $(n=$ 
24, $M=2.08, S D=0.97)$ and those who did not watch the address ( $\mathrm{n}=10, M=1.80, S D$ $=0.79)[t(20.79)=-0.9, p=0.385]$.

\begin{tabular}{|c|c|c|c|c|c|c|c|c|c|}
\hline & & $\begin{array}{l}\text { ontrol } \\
\text { Sroup }\end{array}$ & & & $\begin{array}{l}\text { atmen } \\
\text { roup }\end{array}$ & & $\begin{array}{c}95 \% \text { CI for } \\
\text { Mean Difference }\end{array}$ & & \\
\hline & $M$ & SD & $\mathrm{n}$ & $M$ & SD & $\mathrm{n}$ & & $\mathrm{t}$ & df \\
\hline Satisfaction & 2.30 & 1.49 & 10 & 1.83 & 1.05 & 24 & $-0.447,1.380$ & 0.9 & 12.87 \\
\hline Direction of Nation & 1.44 & 1.01 & 9 & 2.17 & 1.44 & 24 & $-1.789,0.345$ & -1.6 & 20.50 \\
\hline Economic Situation & 2.70 & 0.68 & 10 & 2.78 & 0.74 & 23 & $-0.638,0.473$ & -0.3 & 18.67 \\
\hline Foreign Policy & 2.20 & 0.63 & 10 & 2.48 & 0.89 & 23 & $-0.919,0.363$ & -0.9 & 24.11 \\
\hline Immigration Policy & 1.80 & 0.79 & 10 & 2.00 & 0.89 & 24 & $-0.858,0.458$ & -0.6 & 18.88 \\
\hline Social Justice Policy & 2.00 & 0.82 & 10 & 2.29 & 0.96 & 24 & $-0.995,0.412$ & -0.9 & 19.67 \\
\hline Environmental Policy & 1.80 & 0.79 & 10 & 2.08 & 0.97 & 24 & $-0.993,0.427$ & -0.9 & 20.79 \\
\hline
\end{tabular}

Lastly, the seven-part set of hypotheses $4(A-G)$ predicted that viewers of the 2017 Presidential Inaugural Address who did not vote for the incoming president would report more positive judgments of the state of the nation compared to those who did vote for the incoming president (see Table 4). There was no significant difference in levels of satisfaction of the nation for those who watched the inaugural address and voted for the incoming president $(\mathrm{n}=4, M=2.50, S D=1.29)$ and those who did not vote for the incoming president $(\mathrm{n}=14, M=1.64, S D=1.08)[t(4.46)=1.2, p=0.288]$. There was significant difference in perceptions of the direction the nation is headed for those who watched the inaugural address and voted for the incoming president ( $\mathrm{n}=4, M=4.00, S D$ $=1.41)$ and those who did not vote for the incoming president $(\mathrm{n}=14, M=1.50, S D=$ $0.94)[t(3.79)=3.3, p=0.032]$. There was no significant difference in attitudes about the economic situation for those who watched the inaugural address and voted for the incoming president $(\mathrm{n}=3, M=3.00, S D=1.00)$ and those who did not vote for the incoming president $(\mathrm{n}=14, M=2.79, S D=0.80)[t(2.58)=0.4, p=0.754]$. There was no significant difference in attitudes about foreign policy for those who watched the 
inaugural address and voted for the incoming president $(\mathrm{n}=4, M=2.25, S D=0.50)$ and those who did not vote for the incoming president $(\mathrm{n}=13, M=2.46, S D=1.05)[t$ $(11.41)=-0.6, p=0.592]$. There was no significant difference in attitudes about immigration policy for those who watched the inaugural address and voted for the incoming president $(\mathrm{n}=4, M=2.50, S D=0.58)$ and those who did not vote for the incoming president $(\mathrm{n}=14, M=1.79, S D=0.98)[t(8.57)=1.8, p=0.101]$. There was no significant difference in attitudes about social justice policy for those who watched the inaugural address and voted for the incoming president $(\mathrm{n}=4, M=2.50, S D=0.58)$ and those who did not vote for the incoming president $(\mathrm{n}=14, M=2.14, S D=1.10)[t(9.97)$ $=0.9, p=0.406]$. There was no significant difference in attitudes about environmental policy for those who watched the inaugural address and voted for the incoming president $(\mathrm{n}=4, M=2.75, S D=0.96)$ and those who did not vote for the incoming president $(\mathrm{n}=$ $14, M=1.79, S D=0.98)[t(4.94)=1.8, p=0.138]$.

\begin{tabular}{|c|c|c|c|c|c|c|c|c|c|}
\hline & \multicolumn{3}{|c|}{$\begin{array}{c}\text { Voted for } \\
\text { Incoming President }\end{array}$} & \multicolumn{3}{|c|}{$\begin{array}{l}\text { Did not Vote for } \\
\text { Incoming President }\end{array}$} & \multirow[t]{2}{*}{$\begin{array}{c}95 \% \text { CI for } \\
\text { Mean Difference }\end{array}$} & \multirow[b]{2}{*}{$\mathrm{t}$} & \multirow[b]{2}{*}{ df } \\
\hline & $M$ & SD & $\mathrm{n}$ & $M$ & SD & $\mathrm{n}$ & & & \\
\hline Satisfaction & 2.50 & 1.29 & 4 & 1.64 & 1.08 & 14 & $-1.056,2.770$ & 1.3 & 4.29 \\
\hline Direction of Nation* & 4.00 & 1.41 & 4 & 1.50 & 0.94 & 14 & $-0.371,4.629$ & 3.3 & 3.79 \\
\hline Economic Situation & 3.00 & 1.00 & 3 & 2.79 & 0.80 & 14 & $-1.938,2.367$ & 0.3 & 2.58 \\
\hline Foreign Policy & 2.25 & 0.50 & 4 & 2.46 & 1.05 & 13 & $-1.053,0.630$ & -0.6 & 11.41 \\
\hline Immigration Policy & 2.50 & 0.58 & 4 & 1.79 & 0.98 & 14 & $-0.172,1.601$ & 1.8 & 8.57 \\
\hline Social Justice Policy & 2.50 & 0.58 & 4 & 2.14 & 1.10 & 14 & $-0.561,1.275$ & 0.9 & 9.97 \\
\hline Environmental Policy & 2.75 & 0.96 & 4 & 1.79 & 0.98 & 14 & $-0.442,2.370$ & 1.8 & 4.94 \\
\hline
\end{tabular}

\section{Post-Hoc Results}

While viewing inaugural addresses did not appear to have an impact upon how subjects perceived candidate image or the state of the nation, when compared to those who did not see the address, I noted that participants who ranked perceptions of candidate 
image higher also appeared to rank the state of the nation higher. The two variables were positively correlated $r=.53, \mathrm{p} \leq .01$.

\section{CHAPTER 6: DISCUSSION}

Inaugural addresses present an opportunity for citizens to listen to the president (Chung \& Park, 2010), while he or she aims to create national unity (Beasley, 2001). Presidential speeches have the ability to impact audience perceptions of the president's image and policy agendas (Jacobs \& Shapiro, 2000; Ragsdale, 1984). Thus, this speech event appears to be one artifact to examine the ability of the president to alter perceptions of image and the state of the nation.

I predicted that viewers of the 2017 Presidential Inaugural Address would rate candidate image (competence, trust, reliability, leadership ability, and positive personality traits) higher than those who did not watch the address. Evaluating audience perception of candidate image showed there to be no significant differences with regard to candidate image. I also predicted that viewers who did not vote for the incoming president would report a greater positive perception of candidate image compared to those who voted for the incoming president. There also appeared to be no significant differences among participants.

Turning to the state of the nation, I predicted that viewers of the inaugural address would report more positive judgments than those who did not view the address. Evaluating audience perceptions of the state of the nation showed there to be no significant differences between participants, whether or not they watched the inaugural address. With the last piece of research, I predicted that viewers of the inaugural address who did not vote for the incoming president would report attitudes that are more positive 
about the state of the nation when compared to those who voted for the incoming president. There appeared to be no significant differences between those who voted for the incoming president and those who did not, with one exception.

Participants who voted for the incoming president were significantly more likely to say the nation is "headed in the right direction" when compared with participants who did not vote for the president. I speculate this may have occurred because when measuring judgments of the state of the nation, most of the questions asked participants how they feel "today," with the exception of the question that asked to describe the direction the nation is headed.

Overall, the lack of differences of candidate image perceptions and attitudes about the state of the nation among participants is alarming. The current study suggests that inaugural addresses may not hold as much salience with today's publics as the current literature would suggest. This contradicts prior research from nearly 40 years ago that showed changes to perceptions of candidate image to occur among viewers of the inaugural address (Baas \& Thomas, 1980).

Inaugural addresses act as the formal debut of the incoming president (Zhou \& Kazemian, 2015). However, as social media have become prominent, citizens have a greater potential for advanced exposure to candidates. Throughout the election season, Donald Trump utilized social media platforms for frequent and direct communications to the public. Whether a citizen follows an incoming president on a social media site or explores the broader internet, exposure to a variety of news or other information is likely to occur. 
Citizens may also know where the president stands on different policy areas before the inaugural address. For example, the most viewed debate in American history occurred in 2016 (Kennedy, 2016). In the current study, roughly $87 \%$ of participants viewed at least one election debate, while $20 \%$ watched all three debates. This high level of exposure to the debates may have influenced the impacts of the inaugural address on attitudes.

The 2016 presidential election appears to be unique. There were more republican presidential candidates (16) within the primary season than any time in the past 100 years (Catanese, 2015). This may have created a division among republican voters that the incoming president would have to overcome. The most recent election signaled the first time in American history that a female candidate (former First Lady and Secretary of State Hillary Clinton) was on the ballot for president for a major political party (Dann, 2016). ${ }^{6}$ This was the first time an elected president has had no government experience (Yomtov, 2016). The speech acted as more of a fundraising effort, drawing in $\$ 107$ million, twice as much money as any other inauguration (Confessore, Fandos, \& Shorley, 2017). These occurrences may help us understand why the 2017 inaugural address seemed to have little impact on the study's sample.

The outcome of the election left Donald Trump with a greater number of electoral votes, surpassing the 270 -vote threshold to secure his position. This election signals the fifth time in American history that the incoming president did not win the popular vote (DeSilver, 2016). Trump lost the popular vote for president by the widest margin of any United States President in American history (Kentish, 2016). Hillary Clinton received $48.5 \%$ of voters, while $46.4 \%$ voted for Trump. This yielded an estimated difference of 
2.9 million votes (“2016 Election Results,” 2017). This occurrence may have left many citizens feeling as if Trump did not legitimately acquire his position in office, and therefore, citizens may have evaluated the incoming president, Trump, poorly from the start of his term in office. Audience members may have discounted Trump's inaugural address, regardless of the content of the speech.

When Trump assumed his position as president of the United States, he did so with one of the lowest approval ratings of any incoming president in history (“Obama Leaving," 2017). Not only did Trump enter office with a low rating, but his predecessor, Barack Obama, left office with one of the highest approval ratings of any president (Clement \& Guskin, 2017). Audiences may have expected Trump to follow with a similar agenda. When Trump did not, audiences may not have responded as positively to the inaugural address as prior research would suggest. Scholars also suggest that inaugural speeches are less successful when an incoming president spends more time focusing on his or her new administration and agenda, which Trump has undoubtedly done.

Not only were the approval ratings of Donald Trump much different than those of Barack Obama, but there were other differences between the two inaugural addresses. Trump's inaugural address drew an audience of around 600,000 people, a third of the size of Obama's first inaugural address in 2007, which was attended to by around 1.8 million people (Hunt, 2017). Where Obama's first inaugural address in 2008 drew in roughly 37.8 million television viewers, Trump's inaugural address drew in 19\% less viewers, at roughly 30.6 million (Battaglio, 2017). The difference of audience size may be an indicator of the differences of support between the outgoing president and the incoming 
president, creating another barrier for Trump's inaugural address to overcome when trying to alter the perceptions of audiences.

The current study may also represent a low audience interest. About a third $(33.9 \%)$ of the total study's participants watched "none at all" of the address prior to the experiment taking place, while roughly another third (33.9\%) watched "half or less", and nearly another third (32.2\%) watched "more than half." When asked how much attention was paid to the address (within the treatment condition), $16.7 \%$ of participants paid no attention, and only $4.2 \%$ of participants paid an "extreme amount" of attention to the speech. Therefore, even in a controlled environment, and exposed to the inaugural address, a sixth of participants paid no attention to what was on the screen in front of them.

Inaugural addresses aim to heal wounds, inspire nonpartisanship, and unite society (Beasley, 2001). The inaugural address of Donald Trump did not appear to accomplish these goals. Trump's inaugural address held no call for national unity nor did it appear to draw together all citizens toward a common cause. Although the incoming president spoke about the principles surrounding his administration, the address appeared to be more informational than inspirational. The rhetoric of the speech spoke in a way to inform citizens and celebrate the victory of the incoming president more than to inspire. The speech in question may simply have been atypical, and not representative of overall presidential inaugural addresses.

Following the election of Donald Trump, there were many public demonstrations around the country, with citizens protesting their disapproval of the election outcome (Eversley, Madhani, \& DiBlasio, 2016). In the present study, roughly a third of 
participants $(28.1 \%)$ took part in marches or protests following the election. On the day following Trump's inaugural address, the Women's March on Washington took place. This was the largest citizen demonstration in American history, and signaled a protest of the election of Trump (Chenoweth \& Pressman, 2017). The march set a negative tone for the start of Trump taking his position in office, and may have created a larger divide between the president and the public for those who took part in demonstrations. These protests may have solidified audience perceptions of candidate image or the current state of the nation, limiting the potential ability for the 2017 inaugural address to alter these perceptions.

Each of these stated factors may have contributed to the results of the present study. As witnessed through the findings of the current study, this speech did not accomplish the goals of inaugural addresses historically, when discussing changes to candidate image. If these speeches do not assist the president in ways they have in the past, United States presidents need to discover alternative means to alter audience perceptions of candidate image as intended.

\section{Limitations to Present Study}

This study held some limitations that warrant discussion. First, for analysis of hypotheses, there was a limited sample size of participants. Acquiring participants from a wider net of individuals may have helped to increase the number of individuals who took part in the present study. Another issue regarding the sample is there was little variance among participants. For example, $69.1 \%$ said they were very liberal while $16.4 \%$ were conservative ( $14.5 \%$ of participants labeled themselves as moderate/middle of the road). There were $63.8 \%$ of participants who self-identified as democrats. Only $18.2 \%$ were 
republican (18.2\% labeled their political part identification as independent/neutral). Of participants that voted in the election, $82.4 \%$ indicated they did not vote for the incoming president, while only $17.6 \%$ indicated they did. This disproportionate demographic of participants made it difficult to conduct statistical tests, as participants were broken into many subset groups to test hypotheses. To help address these sample size concerns, expanding it to a wider range of geographical regions by using technology could have helped. While the participants within this study appear to be representative of the political demographics of the geographical region of the present experiment, they are not representative of the larger population of Americans. The results of this study likely do not hold validity to the larger population of focus. Attempting to broaden the range of where participants are from or having a more generalizable sample would help to address such limitations.

While the experiment took place during the same month as the live inaugural address, there was still a gap in time of ten days until the present experiment took place. During that time, the Women's March on Washington took place, Donald Trump signed a variety of executive orders, and social, entertainment, and news media covered widely the inaugural address. Rather than conducting an experiment, which required participants to attend an event and watch the actual footage of the inaugural address after the fact, facilitating a live viewing of the inaugural address could have helped increase the quantity of participants involved. Sending a survey to participants directly after the live inaugural address took place also could have helped remove the influence external factors may have held over results.

\section{Directions for Future Research}


My focus was geared at understanding if a relationship existed between the inaugural address and the audience perceptions of candidate image and the state of the nation; limited data were acquired to better understand the specifics of these findings. Although this study reviewed Ericson's (1997) themes typically found within inaugural address, there was not an analysis conducted as to whether other elements of this 2017 Presidential Inaugural Address followed the typical flow, rhetoric, and overall feeling of addresses. In the future, researchers might attend to the question: How did the inaugural address reflect earlier addresses? I encourage researchers to delve deeply into a rhetorical analysis of the speech to couple with the present study. For example, if Trump did not discuss the environment, a thematic analysis may provide justification for why there was no impact upon audience perceptions of environmental policy.

Other alterations to the research design may have helped glean different results. For example, future studies should further examine each group of participants by administering a pre-survey as well as a post-survey. This would allow for an analysis of change before and after the inaugural address in ways that the present study was unable to examine. Researchers would not only be able to examine changes among groups, but changes within groups.

The political environment has changed since prior studies examined the effects inaugural addresses hold over participant perceptions. Bennett and Iyengar (2008) found that the public is less informed and more polarized than in the past. Nowadays, political messages influence people less, and people self-select messages that conform to and reinforce their predispositions, resisting messages that fall outside their current beliefs. This may help understand why effects from the inaugural address did not present 
themselves. As presidents' audiences become more polarized, inaugural addresses may not be as effective agents of change. Future research should examine the realm of research surrounding the changing trend of political polarization within society, and account for this changing political environment.

Since research of the 1970s and 1980s that examined audience effects of inaugural addresses (e.g. Baas \& Thomas, 1980; Nimmo et al., 1974), there have been many changes within the media environment. Newspaper, radio, and television media were main sources of political news information. Since then, internet and social media platforms are information sources for news. These modern platforms may hold impacts for access to information, knowledge levels, or even attention paid to politics by citizens. By the time the current experiment took place, regardless of whether individuals tuned into the actual footage of the inaugural address, participants may have been exposed to other sources of information about the speech that affected their perceptions. The changing media environment may help explain the lack of findings that were initially expected from the literature. My study did not look into the changing media environment, or the possible effects media exposure may hold upon participants. Future research should look into this area to understand potential audience effects beyond the mere presentation of the inaugural address. 


\section{CHAPTER 7: THE LEARNING EXPERIENCE}

I am at the end of the process of accomplishing the major feat of completing my master's thesis and obtaining my master's degree. Now is the opportunity to reflect upon the growth I underwent throughout this process. Knowing this document would be the largest paper I have written in my life. I understood the large venture I was about to undertake.

From my initial proposal to the final document, my thesis underwent multiple rounds of editing with my thesis advisor. There were times when I was disheartened because entire sets of pages were removed or I would need to completely rewrite a section. Each of these edits was frustrating, but upon reflection, they helped to understand this was just part of the process. With a thesis, there is not one draft and one final version, but rather many different levels of editing that occurred. In the end, my document was much different from initial drafts, but for the better.

I learned to hold my writing to a higher standard and personally grew as a researcher. I cannot believe the changes I have underwent from my first term of graduate school, through the initial stages of my thesis, to completion of the final document. Even when deadlines throughout the process (whether departmental deadlines set for me or deadlines I set for myself) were strenuous and difficult to obtain at times, I continued to push forth. There are times while writing my thesis I found it important to step back and remind myself that I knew what was necessary, and I had the ability to accomplish this feat if I set my mind to it. I can honestly say that I have put more time, energy, and dedication into this document than any other venture in my life. Not only was I able to 
complete this document, but I did so while balancing the workload and time management of various employment opportunities.

While working on my document, I found it helpful to seek out individuals who knew little about scholarly research, or my topic area, and to try to help them understand my document. In the end, if I appropriately wrote my thesis, anyone should be able to understand what I did, regardless of his or her academic background. When I was able to educate others with ease was when I understood just how much growth I have accomplished in graduate school.

This process did not follow a set format that I had expected from the start. There are many twists and turns I faced along the way. I underwent many long days, including times when I was working on physical drafts of my thesis during break opportunities at work, or while commuting to and from campus. This master's thesis and the work I have put forth over the last two years have become the piece of work I am most proud of in my life. I feel that if I am able to accomplish a feat such as this, I am able to accomplish anything else I set my mind to, as long as I continue to grow and develop myself as a person along the way. 


\section{REFERENCES}

2016 Election Results (2017, February 16). Cable News Network. http://www.cnn.com

Baas, L. R., \& Thomas, D. B. (1980). Dissonance and perception during a presidential campaign: Pre- and postelection findings from the carter-ford contest. Journal of Social Psychology, 112(2), 305.

Battaglio, S. (2017, January, 21). Trump's inauguration is watched by 30.6 million viewers - 7 million fewer than Obama's first ceremony. LA Times. http://www.latimes.com

Baum, M. A., \& Kernell, S. (1999). Has cable ended the golden age of presidential television? American Political Science Review, 93, 99-114. doi:10.2307=2585763

Beasley, V. (2001). The rhetoric of ideological consensus in the United States: American principles and American pose in presidential inaugurals. Communication Monographs, 68(2), 169-183.

Bennett, W. L., \& Iyengar, S. (2008). A new era of minimal effects? The changing foundations of political communication. Journal of Communication, 58(4), 707731.

Biria, R., \& Mohammadi, A. (2012). The socio pragmatic functions of inaugural speech: \ A critical discourse analysis approach. Journal of Pragmatics, 44(10), 1290-1302.

Bitzer, L. F. (1992). The rhetorical situation. Philosophy \& Rhetoric, 1-14.

Boydstun, A. E., Glazier, R. A., \& Pietryka, M. T. (2013). Playing to the crowd: Agenda control in presidential debates. Political Communication, 30(2), 254-277.

Branham, R. J., \& Pearce, W. B. (1985). Between text and context: Toward a rhetoric of contextual reconstruction. Quarterly Journal of Speech, 71(1), 19-36. 
Brown, R. E. (2010). Conjuring unity: The politics of the crowd and the poetics of the candidate. American Behavioral Scientist, 54(4), 382-393.

Brubaker, J., \& Hanson, G. (2009). The Effect of Fox News and CNN's Postdebate Commentator Analysis on Viewers' Perceptions of Presidential Candidate Performance. Southern Communication Journal, 74(4), 339-351.

Campbell, K. K., \& Jamieson, K. H. (1978). Form and Genre: Shaping rhetorical action. Speech Communication Association, 2-189.

Campbell, K. K., \& Jamieson, K. H. (1985). Inaugurating the presidency. Presidential Studies Quarterly, 394-411.

Campbell, K. K., \& Jamieson, K. H. (1990). Deeds done in words: Presidential rhetoric and the genres of governance. University of Chicago Press. Chicago

Campbell, K. K., \& Jamieson, K. H. (2008). Presidents creating the presidency: Deeds done in words. University of Chicago Press.

Catanese, D. (2015, July 2). The biggest republican primary in 100 years. US News. http://www.usnews.com

Ceaser, J. W., Thurow, G. E., Tulis, J., \& Bessette, J. M. (1981). The rise of the rhetorical presidency. Presidential Studies Quarterly, 11(2), 158-171.

Cheng, M. (2006). Constructing a new political spectacle: Tactics of Chen Shui-bian's 2000 and 2004 inaugural speeches. Discourse \& Society, 17(5), 583-608.

Chenoweth, E. \& Pressman, J. (2017, February 7). This is what we learned by counting the women's marches. The Washington Post. https://www.washingtonpost.com

Chester, E. W. (1980). Beyond the rhetoric: A new look at presidential inaugural addresses. Presidential Studies Quarterly, 10(4), 571-582. 
Cho, J., \& Choy, S. P. (2011). From podium to living room: Elite debates as an emotional catalyst for citizen communicative engagements. Communication Research, $38(6), 778-804$.

Chung, C. J., \& Park, H. W. (2010). Textual analysis of a political message: The inaugural addresses of two Korean presidents. Social Science Information, 49(2), 215-239.

Clement, S. \& Guskin, E. (2017, January 18). President Obama is leaving office on a very high note. The Washington Post. Retrieved from https://www.washingtonpost.com

Cohen, J. E. (1995). Presidential rhetoric and the public agenda. American Journal of Political Science, 87-107.

Confessore, N.; Fandos, N.; Shorley, R. (2017, April, 19). Trump inaugural address drew big dollar from donors with vested interest. The New York Times. http://www.nytimes.com

Dann, C. (2016, July 27). Hillary Clinton becomes first female nominee of major U.S. political party. NBC News. http://www.nbcnews.com

DeSilver, D. (2016, December 20). Trump's victory another example of how Electoral College wins are bigger than popular vote ones. Pew Research Center. http://www.pewresearch.org

Druckman, J. N., \& Holmes, J. W. (2004). Does presidential rhetoric matter? Priming and presidential approval. Presidential Studies Quarterly, 34(4), 755-778.

Emrich, C. G., Brower, H. H., Feldman, J. M., \& Garland, H. (2001). Images in words: 
Presidential rhetoric, charisma, and greatness. Administrative Science Quarterly, $46(3), 527-557$.

Ericson, D. F. (1997). Presidential inaugural addresses and American political culture. Presidential Studies Quarterly, 27(4), 727-744.

Eshbaugh-Soha, M., \& Peake, J. S. (2005). Presidents and the economic agenda. Political Research Quarterly, 58(1), 127-138.

Eversley, M., Madhani, A., \& DiBlasio, N. (2016, November 9). Thousands across the USA protest Trump victory. USA Today. https://www.usatoday.com

Ford, W. H. (1989). Inaugural addresses of the presidents of the United States. US Government Printing Office.

Fordham, B. (1998). The politics of threat perception and the use of force: A political economy model of US uses of force, 1949-1994. International Studies Quarterly, $42(3), 567-590$.

Gelderman, C. W. (1997). All the presidents' words: The bully pulpit and the creation of the virtual presidency. Walker \& Company.

Hagner, P. R., \& Rieselbach, L. N. (1978). The impact of the 1976 presidential debates: Conversion or reinforcement. In G. F. Bishop et al., (Eds.), The presidential debates: Media, electoral, and policy perspectives (pp.157-178). New York: Praeger.

Hart, R. P., \& Jarvis, S. E. (1997). Political debate forms, styles, and media. American Behavioral Scientist, 40(8), 1095-1122. doi: 10.1177/0002764297040008010 Hill, S. J., Lo, J., Vavreck, L., \& Zaller, J. (2013). How quickly we forget: The duration 
of persuasion effects from mass communication. Political Communication, 30(4), $521-547$.

Hoban Jr, J. L. (1980). Rhetorical rituals of rebirth. Quarterly Journal of Speech, 66(3), 275-288.

Hunt, E. (2017, January 22). Trump's inauguration crowd: Sean Spicer's claims versus the evidence. The Guardian. https://www.theguardian.com

Jacobs, L. R., \& Shapiro, R. Y. (2000). Politicians don't pander: Political manipulation and the loss of democratic responsiveness. University of Chicago Press.

Jamieson, K. H. (1973). Generic constraints and the rhetorical situation. Philosophy \& Rhetoric, 162-170.

Jamieson, K. H., \& Birdsell, D. S. (1988). Presidential debates: The challenge of creating an informed electorate. New York: Oxford University Press.

Jamieson, K. H., \& Campbell, K. K. (1982). Rhetorical hybrids: Fusions of generic elements. Quarterly Journal of Speech, 68(2), 146-157.

Kennamer, J. D. (1987). How media use during campaign affects the intent to vote. Journalism and Mass Communication Quarterly, 64(2), 291.

Kennedy, G. A. (2003). Classical rhetoric and its Christian and Secular tradition from ancient to modern times. University of North Carolina Press.

Kennedy, M. (2016). Clinton-Trump showdown was the most-watched presidential debate ever. National Public Radio. Retrieved from http://www.npr.org.

Kentish, B. (2016, December 12). Donald Trump has lost popular vote by greater margin than any US President. Independent. http://www.independent.co.uk 
Kinnier, R. T., Dannenbaum, S., Lee, D., Aasen, P., \& Kernes, J. L. (2004). Values extolled in US presidential inaugural addresses. Counseling and Values, 48(2), 126.

Korzi, M. J. (2004). The president and the public: Inaugural addresses in American history. In Congress \& the Presidency: A Journal of Capital Studies (Vol. 31, No. 1, pp. 21-52). Taylor \& Francis Group.

Kowal, S., O'Connell, D. C., Forbush, K., Higgins, M., Clarke, L., \& D'Anna, K. (1997). Interplay of literacy and orality in inaugural rhetoric. Journal of Psycholinguistic Research, 26(1), 1-31.

Landreville, K. D., White, C., \& Allen, S. (2015). Tweets, Polls, and Quotes:

Gatekeeping and Bias in On-Screen Visuals During the Final 2012 Presidential Debate. Communication Studies, 66(2), 146-164. doi:

$10.1080 / 10510974.2014 .930919$

Levendusky, M. S. (2010). Clearer cues, more consistent voters: A benefit of elite polarization. Political Behavior, 32(1), 111-131. doi:10.1007/s11109-009-9094-0

McDiarmid, J. (1937). Presidential inaugural addresses-A study in verbal symbols. The Public Opinion Quarterly, 1(3), 79-82.

Miller, A. H., \& MacKuen, M. (1979). Learning about the candidates: The 1976 presidential debates. Public Opinion Quarterly, 43(3), 326-346

Miller, A. H., \& Miller, W. E. (1976). Ideology in the 1972 Election: Myth or Reality-A Rejoinder. American Political Science Review, 70(03), 832-849.

Miller, N. L., \& Stiles, W. B. (1986). Verbal familiarity in American presidential 
nomination acceptance speeches and inaugural addresses (1920-1981). Social Psychology Quarterly, 72-81. Chicago

Mio, J. S., Riggio, R. E., Levin, S., \& Reese, R. (2005). Presidential leadership and charisma: The effects of metaphor. The Leadership Quarterly, 16(2), 287-294. doi: 10.1016/j.leaqua.2005.01.005

Neustadt, R. E. (1991). Presidential power and the modern presidents: The politics of leadership from Roosevelt to Reagan. Simon and Schuster.

Nimmo, D., Savage, R., \& Mansfield, M. (1974). Effects of victory or defeat upon the images of political candidates. Experimental Study of Politics, 3(1), 1-30.

Ochs, E. (1979). Planned and unplanned discourse in discourse and syntax. Syntax and Semantics. Ann Arbor, Mich., 12, 51-80.

Patterson, T. E. (1980). The mass media election: How Americans choose their president. Praeger.

Perelman, C., \& Olbrechts-Tyteca, L. . The New Rhetoric. Trans. J. Wilkinson \& P. Weaver. Nortre Dame: U of Notre

Pew Hispanic Center (2006). Pew Hispanic center national survey of Latinos. (June, 2006). Washington, DC: Pew Research Center. Web. 11 Jan 2017.

Pew Research Center for the People \& the Press (2001). Pew news interest index poll. (June, 2001). Washington, DC: Pew Research Center. Web. 11 Jan 2017.

Pew Research Center for the People \& the Press (2010). Pew research center/national journal congressional connection poll. (June, 2010). Washington, DC: Pew Research Center. Web. 11 Jan 2017.

Pew Research Center for the People \& the Press (2013). Pew research center for the 
people \& the press political survey. (May, 2013). Washington, DC: Pew Research Center. Web. 11 Jan 2017.

Pew Research Center for the People \& the Press (2014). Pew research center for the people \& the press/USA Today political survey. (December, 2014). Washington, DC: Pew Research Center. Web. 11 Jan 2017.

Ragsdale, L. (1984). The politics of presidential speechmaking, 1949-1980. American Political Science Review, 78(04), 971-984.

Ragsdale, L. (1987). Presidential speechmaking and the public audience: Individual presidents and group attitudes. The Journal of Politics, 49(3), 704-736.

Rohler, L. E., \& Cook, R. (1998) Great speeches for criticism and analysis. Alistair Press.

Rosenblatt, A. J. 1998. “Aggressive Foreign Policy Marketing: Public Response to Reagan's 1983 Address on Lebanon and Grenada.” Political Behavior 20, 225-40.

Shull, S. A., \& Ringelstein, A. C. (1993). Assessing Presidential Communication in Civil Rights Policymaking. Policy Studies Journal, 21(3), 522.

Sigelman, L. (1996). Presidential inaugurals: The modernization of a genre. Political Communication, 13(1), 81-92.

Toolin, C. (1983). American civil religion from 1789 to 1981: A content analysis of presidential inaugural addresses. Review of Religious Research, 39-48.

Trump, D. J. (2017, January 20). The inaugural address. Retrieved from http://whitehouse.gov/inaugural-address

Von Drehle, David. (1993, January 20). 42 men in search of the right address. The Washington Post, Fll . 
Weaver, D. (1996). What voters learn from media. The Annals of the American Academy of Political and Social Science, 546, 34-47. Retrieved from http://www.jstor.org/stable/1048168

Wilson, J. (1990). Politically speaking: The pragmatic analysis of political language. Oxford: Basil Blackwell.

Wood, B. D., \& Peake, J. S. (1998). The dynamics of foreign policy agenda setting. American Political Science Review, 92(01), 173-184.

Yomtov, J. (2016, November, 10). Where Trump ranks among least experienced presidents. USA Today. http://www.usatoday.com

Young, G., \& Perkins, W. B. (2005). Presidential rhetoric, the public agenda, and the end of presidential television's “golden age”. Journal of Politics, 67(4), 1190-1205.

Zarefsky, D. (2004). Presidential rhetoric and the power of definition. Presidential Studies Quarterly, 34(3), 607-619. 
APPENDIX A: RECRUITMENT SCRIPT

[To be read aloud to the class when asking for participants]

Thank you for allowing me time to present you with this opportunity. I am conducting a research study to collect information about the perceptions of politics.

Participants in this study should be 18 years of age or older. Participation in this study is completely voluntary and your responses will remain confidential. Choosing to participate or choosing to not participate will NOT negatively impact your course grade in any way. If you choose to participate in this study, you will complete a questionnaire in exchange for extra credit in this course. The survey should take approximately 30 minutes.

If you 1) choose to not participate in this survey, 2) decide to withdraw early, or 3) have already taken this survey for extra credit in another course, you will have the option to complete an alternate extra credit assignment, and should contact one of the researchers.

If you would like to participate in this study, please come to the second story of Cramer Hall $(\mathrm{CH})$, outside of room 183. The study will take no longer than one hour in time for completion. Please arrive no later than $5: 45 \mathrm{pm}$ on Monday, January $23^{\text {rd }}$, as the study will start promptly at 6:00pm. Upon arrival you will complete an informed consent form prior to the study. You will need to write in your first name, last name, and course name and instructor on the consent form in order to receive the extra credit. Your name will only be used for extra credit purposes.

If you choose not to partake in the survey, there will be an alternative reading and writing assignment available of equivalent time and energy. For information about that alternative assignment, please contact the researchers directly.

If you have any questions, feel free to contact the researchers, Kyle Rush at kyrush@pdx.edu or Cynthia Lou Coleman at ccoleman@pdx.edu.

Thank you for your time. Your participation is greatly appreciated! 


\section{APPENDIX B: COURSE WEBSITE POST}

\section{Extra Credit Instructions}

\section{Dear Participant,}

The purpose of this study is to collect information about the perceptions of politics.

Each participant should be at least 18 years of age. If you 1) choose to not participate in this survey, 2) decide to withdraw early, or 3) have already taken the same survey for extra credit in another course, you will have the option to complete an alternate extra credit assignment. Contact me for further directions (not your instructor).

If you would like to participate in this study, please come to the second story of Cramer Hall $(\mathrm{CH})$, outside of room 183. The study will take no longer than one hour in time for completion. Please arrive no later than $4: 30 \mathrm{pm}$ on Monday, January $30^{\text {th }}$, as the study will start promptly at 4:45pm. Upon arrival you will complete an informed consent form prior to the study. You will need to write in your first name, last name, and course name and instructor on the consent form in order to receive the extra credit. Your name will only be used for extra credit purposes.

If you have any questions, feel free to contact the researchers, Kyle Rush at kyrush@pdx.edu or Cynthia Lou Coleman at ccoleman@pdx.edu.

Thank you for your time. Your participation is greatly appreciated! 


\section{Consent}

\section{APPENDIC C: INFORMED CONSENT FORM}

You are invited to participate in a research study conducted by Kyle Rush under the direction of Dr. Coleman for Kyle's Master's Thesis Project. This study attempts to collect information about perceptions of politics. You were selected as a possible participant in this study because you are enrolled as an undergraduate in a communication course.

\section{Procedures}

If you decide to participate, you will be asked to partake in a research study and complete a questionnaire. The study and questionnaire will take approximately one hour or less.

\section{Risks/Discomforts}

Risks are minimal for involvement in this study. However, you may feel uncomfortable when asked to share information about your perceptions of politics, or personal political preferences and decisions. You are welcome to skip any question that you feel uncomfortable answering.

\section{Benefits}

You may not receive any direct benefit from taking part in this study. However, it is hoped that through your participation, the study may help to increase knowledge which may help others in the future.

\section{Confidentiality}

All information that is obtained in connection with this study will be kept confidential and will only be reported in an aggregate format (by reporting only combined results and never reporting individual ones). All questionnaires will be concealed, and no one other than the research team will have access to them. At no point will you name be linked to your answers.

\section{Compensation}

You may earn academic extra credit for your participation. Your consent form will not be linked to your survey responses. Your name is collected only so that your professor may give you extra credit for your class project.

\section{Participation}

Participation in this research study is completely voluntary. You have the right to withdraw at any time or refuse to participate entirely, and it will not affect your course grade in the class or standing with the university. If you wish to receive extra credit but do not wish to complete the survey, contact the researcher for an alternative extra credit opportunity.

\section{Questions about the Research}

If you have questions or concerns regarding this study, contact Kyle Rush at kyrush@pdx.edu or Dr. Coleman atccoleman@pdx.edu

\section{Questions about your Rights as Research Participants}

If you have questions or concerns about your rights as a research subject, please contact Research and Strategic Partnerships, Market Center Building 6th floor, Portland State University, 503-725-4288. By completing this survey, you are certifying that you are 18 years of age or older, that you have read and understand the above information and agree to take part in the study and questionnaire. 
Communication Course you will be using this study participation for:

I certify that I am at least 18 years of age and have read and agreed to the following statements to the best of my ability.

Name of Participant:

Signature of Participant: 


\section{APPENDIX D: SURVEY INSTRUMENT}

Note: Do NOT put your name on this survey. Please complete to the best of your ability before turning in.

For each question, please check the response that best answers the question.

1. How many presidential debates did you watch during the 2016 presidential general election?
[ ] None
[ ] One
[ ] Two
[ ] Three

2. Which of the following is closest to your political ideology?
[ ]
Very
[ ]
Slightly
[ ]
Moderate/
[ ]
[ ]
Liberal
Liberal
Middle of Road
Slightly
Very
Conservative
Conservative

3. Are you registered to vote?
[ ] Yes
[ ] No
[ ] Prefer not to answer

4. Did you vote in the 2016 presidential general election?
[ ] Yes
[ ] No
[ ] Prefer not to answer

5. What is closest to your political party identification?

$\begin{array}{ccccc}{[\text { ] }} & {[]} & {[]} & {[]} & {[]} \\ \text { Strong } & \text { Weak } & \text { Independent/ } & \text { Weak } & \text { Strong } \\ \text { Democrat } & \text { Democrat } & \text { Neutral } & \text { Republican } & \text { Republican }\end{array}$

6. For whom did you vote as President of the United States?

[ ] Hillary Clinton [ ] Gary Johnson [ ] Jill Stein [ ] Donald Trump [ ] Other

7. Please evaluate Donald Trump with how much you believe he possesses the following characteristics.

(Please circle the best answer option for each line)

\begin{tabular}{|c|l|c|c|c|c|}
\hline Competence & None at all & A little & $\begin{array}{c}\text { A moderate } \\
\text { amount }\end{array}$ & A lot & $\begin{array}{c}\text { An extreme } \\
\text { amount }\end{array}$ \\
\hline Reliability & None at all & A little & $\begin{array}{c}\text { A moderate } \\
\text { amount }\end{array}$ & A lot & $\begin{array}{c}\text { An extreme } \\
\text { amount }\end{array}$ \\
\hline $\begin{array}{c}\text { Leadership Ability } \\
\text { None at all }\end{array}$ & A little & $\begin{array}{c}\text { A moderate } \\
\text { amount }\end{array}$ & A lot & $\begin{array}{c}\text { An extreme } \\
\text { amount }\end{array}$ \\
\hline $\begin{array}{c}\text { Positive Personality } \\
\text { Traits }\end{array}$ & None at all & A little & $\begin{array}{c}\text { A moderate } \\
\text { amount }\end{array}$ & A lot & $\begin{array}{c}\text { An extreme } \\
\text { amount }\end{array}$ \\
\hline Trust & None at all & A little & $\begin{array}{c}\text { A moderate } \\
\text { amount }\end{array}$ & A lot & $\begin{array}{c}\text { An extreme } \\
\text { amount }\end{array}$ \\
\hline
\end{tabular}

Please FLIP OVER and complete the opposite side. 
8. All in all, are you satisfied or dissatisfied with the way things are going in this nation today?
[ ]
Very
[ ]
Satisfied
[ ]
Content
[ ]
Dissatisfied
[ ]
Very

Satisfied

9. Please answer the following questions regarding your view of the state of the nation today. (Please circle the best answer option for each line)

\begin{tabular}{|c|l|l|l|l|l|}
\hline Economic Situation & Very Poor & Poor & Okay & Good & Very Good \\
\hline Foreign Policy & Very Poor & Poor & Okay & Good & Very Good \\
\hline Immigration Policy & Very Poor & Poor & Okay & Good & Very Good \\
\hline Social Justice Policy & Very Poor & Poor & Okay & Good & Very Good \\
\hline Environmental Policy & Very Poor & Poor & Okay & Good & Very Good \\
\hline
\end{tabular}

10. All in all, do you think things in the nation are generally headed in the right direction, or do you feel things are headed in the wrong direction?

[ ] $\left[\begin{array}{llll}\text { [ ] } & \text { [ ] } & \text { [ ] } & \text { [ ] }\end{array}\right.$

Greatly in the Slightly in the Staying in Slightly headed in Greatly headed in Right Direction Right Direction the Same Spot the Wrong Direction the Wrong Direction

11. What is your gender?
[ ] Male
[ ] Female
[ ] Non-Binary
[ ] Prefer not to answer

12. What is your race/ethnicity?
[ ] White
[ ] African
[ ] Asian
[ ] Hispanic
[ ] Other
/Caucasian
American
American

13. In what year were you born?

14. Of the 18 minute inaugural address of 2017 , how much did you watch before today?

$\begin{array}{ccccc}{[]} & {[]} & {[]} & {[]} & {[]} \\ \text { None } & \text { Less } & \text { About half } & \text { More } & \text { All of it } \\ \text { at all } & \text { than half } & \text { of it } & \text { than half } & \end{array}$

15. How much attention did you pay to the 2017 inaugural address?
[ ]
[ ]
[ ]
[ ]
None
A little
A moderate
A lot
[ ]
at all
amount
An extreme amount

16. Did you participate in any inauguration protests and/or marches?
[ ] Yes
[ ] No
[ ] Prefer not to answer 


\section{APPENDIX E: PARTICIPANT RESPONSE DATA DETAILS}

\begin{tabular}{|c|c|c|c|c|}
\hline Question Topic & Response Option & $\begin{array}{r}\text { Control } \\
\text { Group } \\
(\mathrm{n}=33)\end{array}$ & $\begin{array}{r}\text { Inaugural } \\
\text { Address } \\
(\mathrm{n}=24) \\
\#(\%)\end{array}$ & $\begin{array}{r}\text { Total of } \\
\text { Groups } \\
(\mathrm{n}=57) \\
\#(\%)\end{array}$ \\
\hline \multicolumn{5}{|l|}{ Political Demographics } \\
\hline \multirow{5}{*}{ Political Ideology* } & Very Liberal & $8(24 \%)$ & $10(42 \%)$ & $18(32 \%)$ \\
\hline & Slightly Liberal & $15(45 \%)$ & $6(18 \%)$ & $21(37 \%)$ \\
\hline & Moderate/Middle of the Road & $6(18 \%)$ & $2(8 \%)$ & $8(14 \%)$ \\
\hline & Slightly Conservative & $1(3 \%)$ & $4(17 \%)$ & $5(9 \%)$ \\
\hline & Very Conservative & $2(6 \%)$ & $2(8 \%)$ & $4(7 \%)$ \\
\hline \multirow[t]{2}{*}{ Registered to Vote* } & Yes & $27(82 \%)$ & $24(100 \%)$ & $51(89 \%)$ \\
\hline & No & $5(15 \%)$ & $0(0 \%)$ & $5(9 \%)$ \\
\hline \multirow[t]{2}{*}{ Voted in Election** } & Yes & $22(67 \%)$ & $18(75 \%)$ & $40(70 \%)$ \\
\hline & No & $11(33 \%)$ & $6(18 \%)$ & $17(30 \%)$ \\
\hline \multirow[t]{5}{*}{ Political Party } & Strong Democrat & $6(18 \%)$ & $9(38 \%)$ & $15(26 \%)$ \\
\hline & Weak Democrat & $18(55 \%)$ & $4(17 \%)$ & $22(39 \%)$ \\
\hline & Independent/Neutral & $5(15 \%)$ & $5(15 \%)$ & $10(18 \%)$ \\
\hline & Weak Republican & $3(9 \%)$ & $4(17 \%)$ & $7(12 \%)$ \\
\hline & Strong Republican & $1(3 \%)$ & $2(8 \%)$ & $3(5 \%)$ \\
\hline \multirow[t]{5}{*}{ Vote for President $* *$} & Hillary Clinton & $16(48 \%)$ & $13(54 \%)$ & $29(51 \%)$ \\
\hline & Gary Johnson & $0(0 \%)$ & $1(4 \%)$ & $1(2 \%)$ \\
\hline & Jill Stein & $2(6 \%)$ & $0(0 \%)$ & $2(4 \%)$ \\
\hline & Donald Trump & $3(9 \%)$ & $4(17 \%)$ & $7(12 \%)$ \\
\hline & Other & $1(3 \%)$ & $4(17 \%)$ & $5(9 \%)$ \\
\hline \multicolumn{5}{|l|}{ Candidate Image } \\
\hline \multirow[t]{5}{*}{ Competence* } & None at All & $13(39 \%)$ & $8(33 \%)$ & $21(37 \%)$ \\
\hline & A Little & $9(27 \%)$ & $8(33 \%)$ & $17(30 \%)$ \\
\hline & A Moderate Amount & $2(6 \%)$ & $4(17 \%)$ & $6(10 \%)$ \\
\hline & A Lot & $6(18 \%)$ & $2(8 \%)$ & $8(14 \%)$ \\
\hline & An Extreme Amount & $2(6 \%)$ & $2(8 \%)$ & $4(7 \%)$ \\
\hline \multirow[t]{5}{*}{ Reliability } & None at All & $18(55 \%)$ & $12(50 \%)$ & $30(53 \%)$ \\
\hline & A Little & $7(21 \%)$ & $5(15 \%)$ & $12(21 \%)$ \\
\hline & A Moderate Amount & $3(9 \%)$ & $4(17 \%)$ & $7(12 \%)$ \\
\hline & A Lot & $5(15 \%)$ & $1(4 \%)$ & $6(10 \%)$ \\
\hline & An Extreme Amount & $0(0 \%)$ & $2(8 \%)$ & $2(4 \%)$ \\
\hline \multirow[t]{4}{*}{ Leadership Ability } & None at All & $10(30 \%)$ & $9(38 \%)$ & $19(33 \%)$ \\
\hline & A Little & $7(21 \%)$ & $6(18 \%)$ & $13(23 \%)$ \\
\hline & A Moderate Amount & $8(24 \%)$ & $5(15 \%)$ & $13(23 \%)$ \\
\hline & A Lot & $4(12 \%)$ & $2(8 \%)$ & $6(10 \%)$ \\
\hline
\end{tabular}




\begin{tabular}{|c|c|c|c|c|}
\hline & An Extreme Amount & $3(9 \%)$ & $2(8 \%)$ & $5(9 \%)$ \\
\hline \multirow[t]{5}{*}{ Positive Personality Traits } & None at All & $22(67 \%)$ & $13(54 \%)$ & $35(61 \%)$ \\
\hline & A Little & $5(15 \%)$ & $7(29 \%)$ & $12(21 \%)$ \\
\hline & A Moderate Amount & $0(0 \%)$ & $3(12 \%)$ & $3(5 \%)$ \\
\hline & A Lot & $6(18 \%)$ & $0(0 \%)$ & $6(10 \%)$ \\
\hline & An Extreme Amount & $0(0 \%)$ & $1(4 \%)$ & $1(2 \%)$ \\
\hline \multirow[t]{5}{*}{ Trust* } & None at All & $22(67 \%)$ & $13(54 \%)$ & $37(65 \%)$ \\
\hline & A Little & $1(3 \%)$ & $5(15 \%)$ & $6(10 \%)$ \\
\hline & A Moderate Amount & $2(6 \%)$ & $3(12 \%)$ & $5(9 \%)$ \\
\hline & A Lot & $3(9 \%)$ & $2(8 \%)$ & $5(9 \%)$ \\
\hline & An Extreme Amount & $2(6 \%)$ & $1(4 \%)$ & $3(5 \%)$ \\
\hline \multicolumn{5}{|l|}{ State of the Nation } \\
\hline \multirow[t]{5}{*}{ Satisfied/Dissatisfied* } & Very Satisfied & $14(42 \%)$ & $11(46 \%)$ & $25(44 \%)$ \\
\hline & Satisfied & $13(39 \%)$ & $9(38 \%)$ & $22(39 \%)$ \\
\hline & Content & $2(6 \%)$ & $2(8 \%)$ & $4(7 \%)$ \\
\hline & Dissatisfied & $1(3 \%)$ & $1(4 \%)$ & $2(4 \%)$ \\
\hline & Very Dissatisfied & $2(6 \%)$ & $1(4 \%)$ & $3(5 \%)$ \\
\hline \multirow[t]{5}{*}{ Economic Situation* } & Very Poor & $1(3 \%)$ & $0(0 \%)$ & $1(2 \%)$ \\
\hline & Poor & $11(33 \%)$ & $9(38 \%)$ & $20(39 \%)$ \\
\hline & Okay & $17(52 \%)$ & $10(42 \%)$ & $27(57 \%)$ \\
\hline & Good & $3(9 \%)$ & $4(17 \%)$ & $7(12 \%)$ \\
\hline & Very Good & $1(3 \%)$ & $0(0 \%)$ & $1(2 \%)$ \\
\hline \multirow[t]{5}{*}{ Foreign Policy* } & Very Poor & $8(24 \%)$ & $4(17 \%)$ & $12(21 \%)$ \\
\hline & Poor & $16(48 \%)$ & $6(18 \%)$ & $22(39 \%)$ \\
\hline & Okay & $6(18 \%)$ & $11(46 \%)$ & $17(30 \%)$ \\
\hline & Good & $2(6 \%)$ & $2(8 \%)$ & $4(7 \%)$ \\
\hline & Very Good & $0(0 \%)$ & $0(0 \%)$ & $0(0 \%)$ \\
\hline \multirow[t]{5}{*}{ Immigration Policy } & Very Poor & $16(48 \%)$ & $8(33 \%)$ & $24(42 \%)$ \\
\hline & Poor & $11(33 \%)$ & $9(38 \%)$ & $20(35 \%)$ \\
\hline & Okay & $4(12 \%)$ & $6(18 \%)$ & $10(18 \%)$ \\
\hline & Good & $2(6 \%)$ & $1(4 \%)$ & $3(5 \%)$ \\
\hline & Very Good & $0(0 \%)$ & $0(0 \%)$ & $0(0 \%)$ \\
\hline \multirow[t]{5}{*}{ Social Justice Policy* } & Very Poor & $12(36 \%)$ & $6(18 \%)$ & $18(32 \%)$ \\
\hline & Poor & $10(30 \%)$ & $7(29 \%)$ & $17(30 \%)$ \\
\hline & Okay & $8(24 \%)$ & $9(38 \%)$ & $17(30 \%)$ \\
\hline & Good & $2(6 \%)$ & $2(8 \%)$ & $4(7 \%)$ \\
\hline & Very Good & $0(0 \%)$ & $0(0 \%)$ & $0(0 \%)$ \\
\hline \multirow[t]{5}{*}{ Environmental Policy } & Very Poor & $16(48 \%)$ & $8(33 \%)$ & $24(39 \%)$ \\
\hline & Poor & $8(24 \%)$ & $8(33 \%)$ & $16(28 \%)$ \\
\hline & Okay & $5(15 \%)$ & $6(18 \%)$ & $11(19 \%)$ \\
\hline & Good & $4(12 \%)$ & $2(8 \%)$ & $6(10 \%)$ \\
\hline & Very Good & $0(0 \%)$ & $0(0 \%)$ & $0(0 \%)$ \\
\hline
\end{tabular}




\begin{tabular}{|c|c|c|c|c|}
\hline \multirow[t]{5}{*}{ Direction of Nation } & Greatly in the Right Direction & $18(55 \%)$ & $12(50 \%)$ & $30(53 \%)$ \\
\hline & Slightly in the Right Direction & $8(24 \%)$ & $4(17 \%)$ & $12(21 \%)$ \\
\hline & Staying in the Same Spot & $1(3 \%)$ & $2(8 \%)$ & $3(5 \%)$ \\
\hline & $\begin{array}{l}\text { Slightly Headed in the Wrong } \\
\text { Direction }\end{array}$ & $3(9 \%)$ & $4(17 \%)$ & $7(12 \%)$ \\
\hline & $\begin{array}{l}\text { Greatly Headed in the Wrong } \\
\text { Direction }\end{array}$ & $1(3 \%)$ & $2(8 \%)$ & $3(5 \%)$ \\
\hline \multicolumn{5}{|l|}{ Political Attention } \\
\hline \multirow[t]{4}{*}{ Debate Viewing } & Watched None & $4(12 \%)$ & $3(12 \%)$ & $7(12 \%)$ \\
\hline & Watched One & $10(30 \%)$ & $5(15 \%)$ & $15(26 \%)$ \\
\hline & Watched Two & $13(39 \%)$ & $10(42 \%)$ & $23(40 \%)$ \\
\hline & Watched Three & $6(18 \%)$ & $3(12 \%)$ & $12(21 \%)$ \\
\hline \multirow{5}{*}{$\begin{array}{l}\text { Prior Inaugural Address } \\
\text { Viewership* }\end{array}$} & None at All & $10(30 \%)$ & $9(38 \%)$ & $19(33 \%)$ \\
\hline & Less than Half & $8(24 \%)$ & $7(29 \%)$ & $15(26 \%)$ \\
\hline & About Half of it & $4(12 \%)$ & $0(0 \%)$ & $4(7 \%)$ \\
\hline & More than Half & $5(15 \%)$ & $0(0 \%)$ & $5(9 \%)$ \\
\hline & All of it & $5(15 \%)$ & $8(33 \%)$ & $13(23 \%)$ \\
\hline \multirow{5}{*}{$\begin{array}{l}\text { Attention Paid to Inaugural } \\
\text { Address } * * * *\end{array}$} & None at All & $3(9 \%)$ & $4(17 \%)$ & $7(12 \%)$ \\
\hline & A Little & $5(15 \%)$ & $5(15 \%)$ & $10(18 \%)$ \\
\hline & A Moderate Amount & $9(27 \%)$ & $4(17 \%)$ & $13(23 \%)$ \\
\hline & A Lot & $6(18 \%)$ & $10(42 \%)$ & $16(28 \%)$ \\
\hline & An Extreme Amount & $2(6 \%)$ & $1(4 \%)$ & $3(5 \%)$ \\
\hline \multirow{3}{*}{$\begin{array}{l}\text { Participation in } \\
\text { Protests/Marches }\end{array}$} & Yes & $7(21 \%)$ & $9(38 \%)$ & $16(28 \%)$ \\
\hline & No & $24(73 \%)$ & $15(63 \%)$ & $39(68 \%)$ \\
\hline & Prefer not to Answer & $2(6 \%)$ & $0(0 \%)$ & $2(4 \%)$ \\
\hline \multicolumn{5}{|c|}{$\begin{array}{l}\text { * Missing data due to participants skipping questions } \\
* * \text { If participant was not registered to vote, but stated voting behavior, response was edited } \\
* * * \text { If participant stated not viewing address, but stated attention paid to it, response was edited }\end{array}$} \\
\hline
\end{tabular}




\section{APPENDIX F: FOOTNOTES}

${ }^{1}$ The eight other themes include civic virtue, federalism, national unity, general policy principles, nonpartisanship, the American mission, political continuity, and defender of the constitution.

${ }^{2}$ The pew Research Center is a nonpartisan political fact tank that conducts public opinion polling

${ }^{3}$ Note: Total voting demographics do not add up to $100 \%$ due to rounding

${ }^{4}$ Two graduate students were recruited, each graduate student proctoring one of the stimulus rooms for the experiment. Prior to the study, each proctor was instructed of the proper protocol for the experiment and how to appropriately interact with participants. Following the study, the graduate students double-checked data to ensure an absence of statistical miscalculation due to human data entry error.

${ }^{5}$ Counseling service resources were made available for participants if they were in need of such services to help minimize potential risks of the study to students.

${ }^{6}$ There have been female presidential candidates during primary elections, third party candidates for general elections, and female Vice-Presidential candidates for general election. 
APPENDIX G: TRANSCRIPT OF 2017 PRESIDENTIAL INAUGURAL ADDRESS

"Chief Justice Roberts, President Carter, President Clinton, President Bush, President Obama, fellow Americans, and people of the world, thank you. We, the citizens of America, are now joined in a great national effort to rebuild our country and to restore its promise for all of our people. Together, we will determine the course of America and the world for many, many years to come. We will face challenges. We will confront hardships, but we will get the job done.

Every four years, we gather on these steps to carry out the orderly and peaceful transfer of power. And we are grateful to President Obama and First Lady Michelle Obama for their gracious aid throughout this process. They have been magnificent. Thank you.

Today's ceremony, however, has very special meaning. Because today we are not merely transferring power from one administration to another, or from one party to another. But we are transferring power from Washington, D.C. and giving it back to you, the people.

For too long, a small group in our nation's Capital has reaped the rewards of government while the people have born the cost. Washington flourished, but the people did not share in its wealth. Politicians prospered, but the jobs left, and the factories closed. The establishment protected itself, but not the citizens of our country. Their victories have not been your victories. Their triumphs have not been your triumphs. And while they celebrated in our nation's capital, there was little to celebrate for struggling families all across our land. That all changes starting right here and right now, because this moment is your moment, it belongs to you. It belongs to everyone gathered here today and everyone watching all across America.

This is your day. This is your celebration. And this, The United States of America, is your country.

What truly matters is not which party controls our government, but whether our government is controlled by the people. January 20th 2017, will be remembered as the day the people became the rulers of this nation again.

The forgotten men and women of our country will be forgotten no longer. Everyone is listening to you now. You came by the tens of millions to become part of a historic movement. The likes of which the world has never seen before. At the center of this movement is a crucial conviction - that a nation exists to serve its citizens. Americans want great schools for their children, safe neighborhoods for their families, and good jobs for themselves. These are just and reasonable demands of righteous people and a righteous public. But for too many of our citizens, a different reality exists: Mothers and children trapped in poverty in our inner cities; rusted-out factories scattered like 
tombstones across the landscape of our nation; an education system, flush with cash, but which leaves our young and beautiful students deprived of all knowledge; and the crime and gangs and drugs that have stolen too many lives and robbed our country of so much unrealized potential. This American carnage stops right here and stops right now.

We are one nation - and their pain is our pain. Their dreams are our dreams; and their success will be our success. We share one heart, one home, and one glorious destiny. The oath of office I take today is an oath of allegiance to all Americans.

For many decades, we've enriched foreign industry at the expense of American industry; subsidized the armies of other countries while allowing for the very sad depletion of our military; we've defended other nation's borders while refusing to defend our own; and spent trillions and trillions of dollars overseas while America's infrastructure has fallen into disrepair and decay. We've made other countries rich while the wealth, strength, and confidence of our country has disappeared over the horizon. One by one, the factories shuttered and left our shores, with not even a thought about the millions upon millions of American workers that were left behind.

The wealth of our middle class has been ripped from their homes and then redistributed all across the world. But that is the past, and now we are looking only to the future. We assembled here today are issuing a new decree to be heard in every city, in every foreign capital, and in every hall of power: from this day forward, a new vision will govern our land. From this day forward, it's going to be only America first. America first. Every decision on trade, on taxes, on immigration, on foreign affairs, will be made to benefit American workers and American families. We must protect our borders from the ravages of other countries making out products, stealing our companies, and destroying our jobs.

Protection will lead to great prosperity and strength. I will fight for you with every breath in my body, and I will never, ever let you down. America will start winning again, winning like never before. We will bring back our jobs, we will bring back our borders, we will bring back our wealth, and we will bring back our dreams. We will build new roads, and highways, and bridges, and airports, and tunnels, and railways all across our wonderful nation. We will get our people off of welfare and back to work. Rebuilding out country with American hands and American labor. We will follow two simple rules: buy American and hire American. We will seek friendship and goodwill with the nations of the world, but we do so with the understanding that it is the right of all nations to put their own interests first. We do not seek to impose our way of life on anyone; but rather, to let it shine as an example. We will shine for everyone to follow. We will reinforce old alliances and form new ones, and unite the civilized world against radical Islamic terrorism, which we will eradicate completely from the face of the earth.

At the bedrock of our politics will be a total allegiance to the United States of America, and through our loyalty to our country, we will rediscover our loyalty to each other. 
When you open your heart to patriotism, there is no room for prejudice. The Bible tells us, "how good and pleasant it is when God's people live together in unity." We must speak our minds openly, debate our disagreements honestly, but always pursue solidarity. When America is united, America is totally unstoppable. There should be no fear - we are protected, and we will always be protected by the great men and women of our military and law enforcement. And most importantly, we will be protected by God.

Finally, we must think big and dream even bigger. In America, we understand that a nation is only living as long as it is striving. We will no longer accept politicians who are all talk and no action - constantly complaining but never doing anything about it. The time for empty talk is over. Now arrives the hour of action. Do not allow anyone to tell you that it cannot be done. No challenge can match the heart and fight and spirit of America. We will not fail. Our country will thrive and prosper again.

We stand at the birth of a new millennium, ready to unlock the mysteries of space, to free the earth from the miseries of disease, and to harness the energies, industries, and technologies of tomorrow. A new national pride will stir ourselves, lift our sights, and heal our divisions. It's time to remember an old wisdom our soldiers will never forget; that whether we are black or brown or white, we all bleed the same red blood of patriots, we all enjoy the same glorious freedoms, and we all salute the same great American Flag. And whether a child is born in the urban sprawl of Detroit or the windswept plains of Nebraska, they look up at the same night sky, they fill their heart with the same dreams, and they are infused with the breath of life by the same almighty Creator.

So to all Americans, in every city near and far, small and large, from mountain to mountain, and from ocean to ocean, hear these words: You will never be ignored again. Your voice, your hopes, and your dreams, will define our American destiny. And your courage and goodness and love will forever guide us along the way.

Together, We Will Make America Strong Again. We Will Make America Wealthy Again. We Will Make America Proud Again. We Will Make America Safe Again. And, Yes, Together, We Will Make America Great Again. Thank you, God Bless You, And God Bless America. 


\section{APPENDIX H: INSTITUTIONAL REVIEW BOARD APPROVAL}

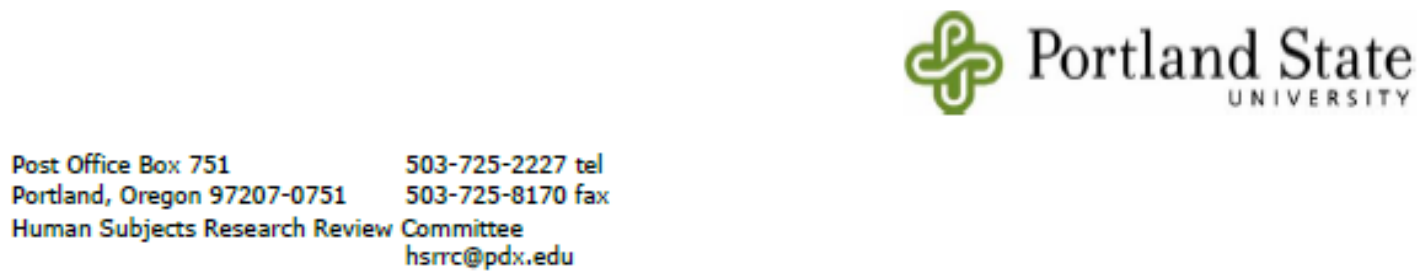

Date: January 20, 2017

To: Cynthia Lou Coleman and Kyle Rush, Department of Communication

From: Lindsey Wilkinson, HSRRC Chair

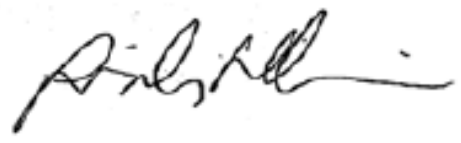

Re: Exempt IRB approval for your project, \#174040, entitled: "Influence of Inaugural Addresses on Presidential and National Image Levels"

Review Type: Exempt, Category 2

In accordance with your request, the Human Subjects Research Review Committee has reviewed your proposal referenced above for compliance with PSU policies, and DHHS regulations 45 CFR 46 , covering the protection of human subjects. The Committee is satisfied that your provisions for protecting the rights and welfare of all subjects participating in the research are adequate, and your project is approved. Please note the following requirements:

Approval: You are approved to conduct this research study after receipt of this approval letter; and the research must be conducted according to the plans and protocol submitted (approved copy enclosed).

Consent: You must use IRB-approved consent materials with study participants.

Changes to Protocol: Any changes in the proposed study, whether to procedures, survey instruments, consent forms or cover letters, must be outlined and submitted to the Committee immediately. The proposed changes cannot be implemented before they have been reviewed and approved by the Committee.

Adverse Reactions and/or Unanticipated Problems: If any adverse reactions or unanticipated problems occur as a result of this study, you are required to notify the Committee immediately. If the issue is serious, approval may be withdrawn pending an investigation by the Committee.

Completion of Study: Please notify the Committee as soon as your research has been completed. Study records, including protocols and signed consent forms for each participant, must be kept by the investigator in a secure location for three years following completion of the study (or per any requirements specified by the project's funding agency).

If you have questions or concerns, please contact the Office of Research Integrity in the PSU RSP at 503-725-2227, 1600 SW $4^{\text {th }}$ Ave., Market Center Building, Suite 620. 